\title{
Masculinities, Post-Racialism AND the Gates Controversy: The False Equivalence BetweEN OFFICER AND CiviLIAN
}

\author{
Frank Rudy Cooper*
}

\section{INTRODUCTION}

Suppose you read in the newspaper that a police officer responded to a report of a potential break-in and that he subsequently arrested the homeowner. Would those be enough facts to explain why the arrest occurred? ${ }^{1}$

No? Let us assume the reporter added the following facts: The officer arrived at the home and found a person inside. ${ }^{2}$ The officer asked the civilian to join him on the porch. ${ }^{3}$ The civilian refused to do so. ${ }^{4}$ The officer said there was a report of a potential break-in. ${ }^{5}$ The civilian became offended at being suspected of the break-in. ${ }^{6}$ An argument ensued, during which the civilian

* Copyright (C) 2011 Frank Rudy Cooper. All rights reserved. Professor of Law, Suffolk University Law School. Special thanks to Ann Brown, Suffolk '09, for assistance above and beyond the call of duty. I also thank my research assistant, Lia Marino. Further thanks to Rick Buckingham, Joseph Franco, Diane Juliar, Christopher Lasch, Angela OnwuachiWillig, Andrew Perlman, Josephine Ross, Ann McGonigle Santos, Ragini Shah, and Linda McClain's 2009 B.U. Gender Colloquium class. This Article was honed by presentations at the Feminism and Legal Theory Project's 2009 Masculinities Conference, the 2009 LatCrit Conference, and a 2009 Washington \& Lee Faculty Colloquium. Special thanks to the Nevada Law Journal for editorial excellence. For further masculinities analyses, please see Masculinities and Law: A Multidimensional Approach (Frank Rudy Cooper \& Ann C. McGinley eds., N.Y. Univ. Press forthcoming 2011). The author may be reached at fcooper @ suffolk.edu.

1 Interestingly, a bland search ("police officer report of break-in arrest") of LexisNexis's news database for the last 90 days before August 13, 2009, yielded disparate results, including stories about James Crowley's arrest of Henry Louis Gates Jr., which is the subject of this Article. See, e.g., Alfred Adams, Ghana; AG Frees Two Interdicted Police Officers, Ghanaian Chronicle, July 24, 2009, available at http://allafrica.com/stories/200907240 931.html (reporting on freeing of police officers unrelated to Gates's arrest); Melissa Trujillo, Police Responding to Break-in Report Arrest Top Scholar in His Home, IrIsH ExamINER, July 22, 2009 (World), available at http://www.irishexaminer.com/world/sngbsnqley/ rss2/ (reporting Gates's arrest); Melissa Trujillo, My Arrest Was Racial Profiling, Pre-eminent Black Scholar Says, Virginian-Pilot, July 21, 2009, at A4 (reporting Gates's arrest).

2 See generally James Crowley, Cambridge Police Department Incident Report \# 9005127, THE SMOKING GUN, (July 16, 2009, 1:21 PM), http://www.thesmokinggun.com/file/henrylouis-gates-jr-police-report [hereinafter Crowley, Incident Report] (detailing event).

3 Id. at 2.

${ }^{4} I d$.

$5 \mathrm{Id}$.

6 See id. (describing Gates's reaction). 
spoke loudly. ${ }^{7}$ The argument continued as spectators gathered and other officers arrived. ${ }^{8}$ Eventually, the civilian stepped onto the porch. ${ }^{9}$ The first officer then arrested the civilian for disorderly conduct. ${ }^{10}$ Would those be enough facts to fully explain the arrest?

Maybe? Let us assume further you learn the following facts. Both the first officer and the arrestee are men. The officer is relatively tall and burly. ${ }^{11}$ The arrestee is relatively short and slight and walks with a limp. The officer alleges the arrestee made derogatory comments about his mother. ${ }^{12}$ At this point, it might occur to you that something about masculinity was influencing these events. After all, cops are known to be pretty macho and smaller men might be particularly reluctant to back down from a conflict, lest their stature be viewed as a vulnerability. ${ }^{13}$

Suppose further that the arrest became a national controversy. What could explain the fact that all forms of media covered the story in detail for more than a week $?^{14}$ How about the fact that officer James Crowley is white and the suspect, Professor Henry Louis Gates Jr., is black? ${ }^{15}$ Additionally, Crowley claims a witness told him two black men forcibly opened the front door. ${ }^{16}$ The witness, who says she is not white, but "olive-skinned," denies telling Crowley two black men forcibly opened the front door. ${ }^{17}$ Moreover, Gates called Crowley a racist and shouted, "THIS IS WHAT HAPPENS TO BLACK MEN IN AMERICA!" as he was arrested. ${ }^{18}$

Now it might seem this event was about race. Race could have influenced either Crowley's suspicion of Gates or his decision to arrest him. ${ }^{19}$ It certainly influenced Gates's charge of racism. The affair only died down because

7 Id.

$8 I d$.

9 Id.

${ }_{10} I d$.

11 Observations about the parties' physical states are based on the author's visual inspection of pictures of the parties.

12 Crowley, Incident Report, supra note 2, at 2.

13 See, e.g., Frank Rudy Cooper, “Who's the Man?”: Masculinities Studies, Terry Stops, and Police Training, 18 Colum. J. Gender \& L. 671, 693-98 (2009) [hereinafter Cooper, Who's the Man?] (describing not backing down as part of the hegemonic pattern of police officer masculinity).

14 See Michael O'Brien, Obama's 'Beer Summit' Cools Racial Controversy, The Hill, July 31, 2009, at 6 (saying Gates controversy "dominated the past couple of weeks").

15 This assertion is based on the author's visual inspection of pictures of the parties. That the parties' races are rarely mentioned in a controversy that was explicitly about race is telling.

16 Crowley, Incident Report, supra note 2, at 1.

17 See Russell Contreras, 'Keep the Cars Coming', Newsday (Long Island), July 28, 2009, at A7 (describing controversy over Whalen's alleged statement).

18 Carlos Figueroa, Cambridge Police Department Incident Supplement \#9005127-1, THE SMOKING GUN (July 16, 2009, 1:51 PM), http://www.thesmokinggun.com/file/henry-louisgates-jr-police-report [hereinafter Figueroa, Incident Supplement].

19 This possibility is suggested by the extensive literature on implicit bias, especially that addressing police officers. See generally, e.g., Jerry Kang, Trojan Horses of Race, 118 HARv. L. Rev. 1489 (2005) (describing how implicit bias affects behavior); see also, e.g., Anthony C. Thompson, Stopping the Usual Suspects: Race and the Fourth Amendment, 74 N.Y.U. L. REv. 956, 983-87 (1999) (describing how stereotypes lead police officers to racial profile). 
Barack Obama-the black president of this majority white nation, who had himself strode into the fray by saying the police acted "stupidly"-hosted a socalled "beer summit." ${ }^{20}$ Crowley and Gates had a détente with the president and vice president at the White House. ${ }^{21}$ A year later, the City of Cambridge Review Committee (Committee) issued a report concluding that Crowley and Gates had "shared responsibilities" for the arrest. ${ }^{22}$

So, is this case about machismo or race? Although commentary on this case has generally concentrated on the question of whether Gates's arrest was race-based, ${ }^{23}$ some have answered in the negative on the grounds the arrest was mostly the product of machismo. ${ }^{24}$ In fact, the masculinity-based and racebased explanations are both correct. The arrest and its aftermath can only be fully understood by viewing the events in a multidimensional way that acknowledges that gender and race (as well as class and other identities) operate simultaneously, inextricably, and in a context-dependent manner. ${ }^{25}$

20 See Nancy Benac, Obama Looks to Quiet Racial Flap, Invites Cop, Scholar for a Beer, STAR-Ledger (Newark), July 25, 2009, at 3 (reporting summit); O'Brien, supra note 14, at 6 (referring to the meeting as "Obama's 'beer summit" ").

21 Benac, supra note 20, at 3.

22 Missed Opportunities, Shared Responsibilities: Final Report of The Cambridge Review Committee 3-4, (2010), available at http://www.cambridgema.gov/CityOfCambridge_Content/documents/Cambridge\%20Review_FINAL.pdf [hereinafter MisseD OpPORTUNITIES].

23 Compare Matt Murphy, Cop Accused in Professor's Arrest Teaches on Racial Profiling at Lowell Police Academy, Lowell Sun (Mass.), July 24, 2009 (doubting racial profiling allegation), with John Doherty, Forum Sought on Race, Police: Harvard Professor's Arrest Spurs Syracuse Civil Rights Group's Push for Dialogue, Post-Standard (Syracuse), Aug. 2, 2009, at B-3 (noting local group's use of Gates's arrest to promote anti-racial profiling training).

24 See, e.g., Joan Vennochi, Opinion, Machismo and the Gates Incident, Boston Globe, July 23, 2009, at 17 (arguing both parties' machismo was largest cause of Gates's arrest).

25 See Athena D. Mutua, Theorizing Progressive Black Masculinities, in Progressive Black Masculinities 3, 22-24 (Athena D. Mutua ed., 2006) (defining multidimensionality theory); see also Darren Lenard Hutchinson, "Gay Rights" for "Gay Whites"?: Race, Sexual Identity, and Equal Protection Discourse, 85 Cornell L. Rev. 1358, 1362-68 (2000) [hereinafter Hutchinson, "Gay Rights" for "Gay Whites"?] (defining multidimensionality theory in contrast to intersectionality theory).

Professor Darren Hutchinson is often credited with creating multidimensionality theory. In his article, "Gay Rights" for "Gay Whites"?, Hutchinson defines multidimensionality theory as seeking to "reveal the "host of interlocking sources of advantage and disadvantage' that sustain the 'various institutions of oppression' and corresponding identity categories." $I d$. at 1368 (quoting Darren Lenard Hutchinson, Ignoring the Sexualization of Race: Heteronormativity, Critical Race Theory and Anti-Racist Politics, 47 Buff. L. Rev. 1, 10 (1999) (distinguishing multidimensionality theory from intersectionality theory)). Hutchinson contrasts multidimensionality theory with its predecessor, intersectionality theory. In a nutshell, intersectionality theory says that people in whom multiple subordinated categories of identity intersect, such as black women, have unique subjective experiences of the world and face unique forms of discrimination. See generally Frank Rudy Cooper, Against Bipolar Black Masculinity: Intersectionality, Assimilation, Identity Performance, and Hierarchy, 39 U.C. Davis L. Rev. 853 (2006) [hereinafter Cooper, Against Bipolar Black Masculinity] (applying intersectionality theory to black men).

For a multidimensional approach to the Gates controversy, see Hope Lewis, Race in America: Moments and Years (I), InTlawGrrls (Aug. 5, 2009, 9:39 AM), http://intlawgrrls. blogspot.com/2009/08/race-in-america-moments-and-years.html; Hope Lewis, Race in 
A multidimensional analysis of the Gates arrest adds two important insights to the discussion. First, the arrest was a product not only of racial profiling ${ }^{26}$ but also of a masculinity contest-a confrontation where one person will boost his internal or attributed ${ }^{27}$ masculine esteem at the expense of the other. ${ }^{28}$ Second, the public's response to Gates's claim of racism was so negative because of an ever-increasing pressure to be colorblind in this supposedly "post-racial" culture. ${ }^{29}$ This Article thus concludes that the Cambridge

America: Moments and Years (II), IntLawGrrls (Aug. 6, 2009, 7:02 AM), http://intlaw grrls.blogspot.com/2009/08/race-in-america-moments-and-years_06.html.

26 "Racial profiling" occurs when there is (1) a categorization of certain people as "races," (2) a "profile" that describes the implications of a racial status, and (3) a "profiler" who applies the profile to a member of that race as a basis for making a decision about that person. Frank Rudy Cooper, The Un-Balanced Fourth Amendment: A Cultural Study of the Drug War, Racial Profiling and Arvizu, 47 ViLl. L. Rev. 851, 852 n.9 [hereinafter Cooper, The Un-Balanced Fourth Amendment] (defining racial profiling in critique of the drug war); see also Neil Gotanda, Comparative Racialization: Racial Profiling and the Case of Wen Ho Lee, 47 UCLA L. REv. 1689, 1691 (2000) (identifying components of racial profiling in context of false accusation that Chinese-American scientist was a spy). See generally Kevin R. Johnson, How Racial Profiling in America Became the Law of the Land: United States v. Brignoni-Ponce and Whren v. United States and the Need for Truly Rebellious Lawyering, 98 Geo. L.J. 1005 (2010) (comparing key Supreme Court cases governing racial profiling).

One might also see Crowley's arrest of Gates as a sort of "reverse class profiling" whereby a working-class cop from a town dominated by a university stereotypes a privileged professor as a trouble-maker. See discussion infra note 147 (summarizing how class influenced the arrest). Such a view would still need to account for race. An analysis of the class aspects of Crowley's arrest of Gates is beyond the scope of this Article.

27 "Attributed" masculine esteem is how others perceive an individual's manliness. See Devon W. Carbado \& Mitu Gulati, Working Identity, 85 Connell L. Rev. 1259, 1261 n.2 (2000) (contrasting "self identity," "attributal identity," and the process of "working identity," or providing signals about one's identity). Attributions of masculine esteem will vary based on the intersectionality of identities. See, e.g., Cooper, Against Bipolar Black Masculinity, supra note 25, at 855-56 (defining intersectionality theory). Accordingly, black women's experiences are not captured by considering only the experiences of black men or white women or even adding those two experiences together. Id. at 856. Unfortunately, black women's interests have sometimes been subordinated to those of black men or white women in anti-racist and feminist organizations. See Hutchinson, "Gay Rights" for "Gay Whites"?, supra note 25, at 1362-63 (noting insights intersectionality theory developed). According to Hutchinson, multidimensionality theory extends intersectionality theory in both substantive and conceptual ways. Id. at 1363 . Substantively, multidimensionality theorists have looked at issues intersectionality theorists neglected, particularly, heterosexism. See id. at 1363-64 (defining multidimensionality's substantive contributions). Hutchinson admits that "multidimensionality is not a wholly alternative paradigm." Darren Lenard Hutchinson, Out Yet Unseen: A Racial Critique of Gay and Lesbian Legal Theory and Political Discourse, 29 Conn. L. Rev. 561, 641 (1997). Conceptually, multidimensionality theory allows for the consideration of how people are not just multiply subordinated, but often both subordinated and privileged at the same time. Hutchinson, "Gay Rights" for "Gay Whites"?, supra note 25 , at 1367-68 (contrasting multidimensionality theory with intersectionality theory). For an example of a similar methodology applied to police behavior, see Peter Kwan, Jeffrey Dahmer and the Cosynthesis of Categories, 48 Hastings L.J. 1257, $1257-58,1281-85$ (1997) (applying "cosynthesis theory" to a police decision not to arrest a white male serial killer in the face of a report of suspicious activity).

28 See Cooper, Who's the Man?, supra note 13, at 698-701 (defining masculinity contest). 29 On the critique of "post-racialism," see Anthony V. Alfieri, Post-Racialism in the InnerCity: Structure and Culture in Lawyering, 98 Geo L.J. 921, 924-27 (addressing post-racialism in the context of lawyering on inner-city cultures); Mario L. Barnes, Reflection on a 
Review Committee's drawing of an equivalence between Crowley and Gates as having "shared responsibilities" for the arrest is symptomatic of what happens when machismo meets post-racialism. This is a false equivalence: as a police officer, Crowley is duty-bound to keep the peace and trained to deal with conflict; as a civilian, Gates is neither obligated nor trained to keep his cool.

To make that argument, this Article proceeds as follows. Part II tells the stories of the arrest, the public response, the Massachusetts disorderly conduct statute, and the Cambridge Review Committee's report. Part III conducts a masculinities studies analysis of the arrest. $^{30}$ It shows the arrest can be conceived of as resulting from the ways the parties challenged each other's masculinities, ${ }^{31}$ which resulted in a masculinity contest. ${ }^{32}$ Specifically, Gates's

Dream World: Race, Post-Race and the Question of Making It Over, 11 Berkeley J. Afr.AM. L. \& Pol'y 6, 11-14 (critiquing notion that we are "post-race"); Mario L. Barnes, Erwin Chemerinsky \& Trina Jones, A Post-race Equal Protection?, 98 Geo. L.J. 967, 972 (2010) (arguing for pursuit of alternative equal protection theories in light of post-racial culture); Christopher A. Bracey, The Color of Our Future: The Pitfalls and Possibilities of the Race Card in American Culture, 5 StAn. J. C.R. \& C.L. 89, 91, 97-98 (2009) (book review) (arguing whites "play the race card" by accepting past and present benefits of white status); Sumi Cho, Post-Racialism, 94 Iowa L. Rev. 1589, 1595-96 (2009) (arguing post-racialism absolves whites of responsibility for past and present racism); Ian F. Haney López, PostRacial Racism: Racial Stratification and Mass Incarceration in the Age of Obama, 98 CALIF. L. Rev. 1023, 1062-64 (2010) (arguing colorblindness has led people to accept racial stratification in criminal justice system); john a. powell, Post-Racialism or Targeted Universalism?, 86 Denv. U. L. Rev. 785, 789 (2009) (critiquing post-racialism as a cover for ongoing white supremacy); Julie C. Suk, Race Without Cards?, 5 STAN. J. C.R. \& C.L. 111 (2009) (book review); Christian B. Sundquist, Science Fictions and Racial Fables: Navigating the Final Frontier of Genetic Interpretation, 25 HaRv. BlackLetter L.J. 57, 82-93 (2009) (critiquing new forms of criminal profiling); Angela Onwuachi-Willig, An Officer and a Gentleman: A "Post-Racial" Arrest (2009) (unpublished manuscript) (on file with author) (discussing the impact of the "post-racial" discourse on the Gates discussion). See generally Symposium, Defining Race, 72 Alb. L. Rev. 855 (2009) (collecting essays addressing current racial issues).

30 The field of masculinities studies describes the ways assumptions about the meanings of manhood are used to justify particular ideologies, institutions structures, and individual behaviors. Gail Bederman, Manliness and Civilization: A Cultural History of GenDeR ANd Race in the United States 1880-1917, at 7 (1995) (defining the field as considering how ideologies about manhood gain ascension and influence behavior). Recent masculinities studies articles include: David S. Cohen, No Boy Left Behind? Single-Sex Education and the Essentialist Myth of Masculinity, 84 IND. L.J. 135, 187 (2009) (arguing recent boys school movement reinforces hegemonic masculinity); Ann C. McGinley, Creating Masculine Identities: Bullying and Harassment "Because of Sex," 79 U. Colo. L. Rev. 1151, 1240-41 (2008) (arguing masculinities studies shows male-male bullying should give rise to discrimination claim). Among the masculinities and criminal justice literature, see especially, Cooper, Who's the Man?, supra note 13, at 678 (applying masculinities studies to Terry stops to argue for new police training); Angela P. Harris, Gender Violence, Race, and Criminal Justice, 52 StAN. L. REv. 777, 777 (2000) (analyzing how masculinity effects the criminal justice system); and Joan W. Howarth, Representing Black Male Innocence, $1 \mathrm{~J}$. GENDER RACE \& JusT. 97, 100-01 (1997) (arguing stereotypes of black male criminality affect jury decisions). For a collection of articles on masculinities and law, see MAsculinIties and Law: A Multidimensional Approach (Frank Rudy Cooper \& Ann C. McGinley eds., N.Y. Univ. Press forthcoming 2011) (collecting new masculinities scholarship).

31 A "masculinity challenge" occurs when one is threatened or expectations of masculine behavior are unachievable. James W. Messerschmidt, Becoming "Real Men": Adolescent Masculinity Challenges and Sexual Violence, in 2 Men \& MAsculinities 286, 298 (2000) 
violation of the unofficial rule of deference to the badge ${ }^{33}$ created a masculinity challenge for Crowley, resulting in a masculinity contest between the parties that Crowley resolved by arresting Gates. Part IV explains why post-arrest criticism of Gates should be seen as largely a product of the majority of the public's adoption of a post-racial ideology. Whereas colorblind ideology presumes the best way to reach an egalitarian society is to pretend race does not matter, ${ }^{34}$ post-racial ideology assumes we have reached that state. ${ }^{35}$ The ironic result of Obama's election is that it made it harder for the majority of the public to see Crowley as implicitly biased and easier for them to see Gates as the true racist for having called Crowley racist. ${ }^{36}$ Part $\mathrm{V}$ concludes by linking the analyses of machismo and post-racialism in a criticism of the creation of a false equivalence between police officers and civilians. ${ }^{37}$

\section{The Story(IES)}

Part of the reason the Gates affair so thoroughly captured the public's imagination for more than two weeks in the summer of 2009 is that it involved three very interesting characters. One was a working-class Irish kid who had made good and moved from the city to the suburbs but still policed his

[hereinafter Messerschmidt, Becoming Real Men]; see also Cooper, Who's the Man?, supra note 13, at 698 n.152 (discussing Messerschmidt's theory); discussion infra Part III.A.3 (comparing and contrasting masculinity challenge and "masculinity contest").

32 A "masculinity contest" occurs when each of two or more people are subject to a masculinity challenge and only one person or one side will be able to boost their internal or attributed masculine esteem. Cooper, Who's the Man?, supra note 13, at 674 (defining term). See also discussion infra Part III.A.3 (comparing and contrasting masculinity challenge and masculinity contest).

33 See Cooper, Who's the Man?, supra note 13, at 697-98 (defining unwritten rule of deference to the badge).

34 See Cho, supra note 29, at 1597-98 (distinguishing colorblindness and post-racialism).

35 See id. at 1595-96 (noting post-racialism's triumphalism).

36 See Victor Davis Hanson, Op-Ed., America Has Moved Beyond Race, and the PresidentShould, Too, The Mercury News (San Jose), July 22, 2010, http://www.mercurynews.com/ ci_15577067. See also Russell K. Robinson, Perceptual Segregation, 108 Colum. L. Rev. 1093, 1098 (2008) (defining perceptual segregation as distinct points of view on the part of blacks and whites as to what constitutes discrimination).

37 A note on this Article's method of analysis: treating the Gates arrest and subsequent controversy as largely a product of masculinities or race alone in Parts III and IV is done strictly for heuristic purposes. See Devon W. Carbado \& Mitu Gulati, What Exactly is Racial Diversity?, 91 CALIF. L. Rev. 1149, 1154 (2003) (book review) (declaring that "while the functions of diversity we identify are overlapping and interconnected, for heuristic purposes we articulate them separately"). The analysis is cleaner and more easily understood when we discuss masculinities and race mostly in isolation. This is so because it is easier to prove masculinities or race were involved at all by largely isolating the particular identity's influence on the Gates controversy. It then becomes easier to see that the arrest and the whole controversy were the products of the combination of masculinities and race, which are imbricated within one another. Considering the identities in isolation sets the stage for the background assumption that any given cultural event is always the product of the specific mixture of masculinities, race, and other identities interacting with the time, place, and other aspects of the cultural context in play. See Frank Rudy Cooper, The "Seesaw Effect" from Racial Profiling to Depolicing: Toward A Critical Cultural Theory, in The New CiviL Rights Research: A Constitutive Approach 139, 153 (Benjamin Fleury-Steiner \& Laura Beth Nielsen eds., 2006) (emphasizing the significance of cultural context). 
hometown. The other was a world-famous black male professor at one of the world's most well-known universities. And then there was the President of the United States, Barack Obama, also a black male, who managed to become the leader of this country despite being a racial minority.

The incident also highlighted significant social issues that have divided the country. The obvious one was race, which has literally rent this nation asunder $^{38}$ and simmers beneath many political issues. ${ }^{39}$ Here, it was represented by the issue of racial profiling, which drew the nation's attention prior to September 11, 2001, but seems to have faded into a non-controversy. ${ }^{40}$ There were also class issues represented by the dichotomy between the "townie" cop and the privileged professor. ${ }^{41}$ Lastly, but quite significantly, was the issue of machismo, which made a rare appearance in our public thought thanks to the "pissing contest" between these parties. ${ }^{42}$

However, although this drama begs to be interpreted, its analysis is not self-executing. Many people have argued this affair is primarily about gender ${ }^{43}$ or primarily about race. ${ }^{44}$ Both perspectives are wrong, and both perspectives are right. To begin the process of demonstrating why that is so, the next Part of this Article summarizes what the stories of Crowley, Gates, Obama, the Massachusetts disorderly conduct law, and the Cambridge Review Commission report tell about this controversy.

\section{A. Crowley's Report}

Crowley begins the substantive part of his Incident Report by noting that he was uniformed and on the 7:00 a.m. to 3:30 p.m. shift when the relevant events occurred. ${ }^{45}$ At approximately 12:44 p.m., he was driving on Harvard Street, near Ware Street in the Harvard Square area. ${ }^{46}$ He overheard an ECC broadcast of a possible break-in in progress on Ware Street. ${ }^{47}$ Lucia Whalen made the 911 call. $^{48}$ She does not initially identify the race of the two men she alleges forced the door open. ${ }^{49}$ She does state, upon inquiry, that one of the men may have been Hispanic. ${ }^{50}$

Crowley's Incident Report states he responded to the dispatcher's call because he was nearby. ${ }^{51}$ According to the Incident Report, which a recording

38 Think of both the Civil War and ongoing racial segregation.

39 See Robinson, supra note 36, at 1100 (discussing increasing divide between white and black views on what constitutes discrimination).

40 See Johnson, supra note 25, at 1006 (noting "surprising" nature of long-standing Supreme Court condonance of racial profiling).

41 Chuck Wexler \& John J. Farmer, Jr., Race-It's Not All Black and White, Boston Globe, July 17, 2010, at A11 (noting town/gown split).

42 See Vennochi, supra note 24, at A17 (emphasizing male-male gender dynamic).

43 See id. (arguing machismo partially explains the arrest).

44 See, e.g., Doherty, supra note 23, at B-3 (noting claims that race explains the arrest).

45 Crowley, Incident Report, supra note 2, at 1.

$46 I d$.

47 Id. The number on Ware Street is obscured in the published Incident Report.

48 Contreras, supra note 17 , at A7.

49 Id.

$50 \mathrm{Id}$.

51 Crowley, Incident Report, supra note 2, at 1. 
corroborates on this point, ${ }^{52}$ Crowley asked the witness to meet him at the residence. ${ }^{53}$ As he climbed the porch and reached the front door of Gates home Whalen called out to him. ${ }^{54}$ The report continues, "She went on to tell me that she observed what appeared to be two black males with backpacks on the porch." ${ }^{55}$ Later, Whalen denied she ever specified that the suspects were black. ${ }^{56}$ Crowley further claims "[Whalen] told me that her suspicions were aroused when she observed one of the men wedging his shoulder into the door as if he was trying to force entry." 57 This might also contradict Whalen's account, as the recording describes her as calling on behalf of an older woman who was the one who saw the events in full. ${ }^{58}$ Invoking officer safety, Crowley's Incident Report then states that because he was the only police officer on the scene and had his back to the door, he broke off his conversation with Whalen in order to face the door. ${ }^{59}$

At this point, Crowley says he saw an older black man in the foyer. ${ }^{60}$ Apparently concerned to explain how he could see the man who turned out to be Gates, Crowley says he could see through the glass of the front door. ${ }^{61}$ In language drawn from case law, Crowley states he stood in "plain view" of Gates. ${ }^{62}$ With the door still shut, Crowley asked if Gates would step onto the porch and speak with him, ${ }^{63}$ to which Gates replied, "[N]o, I will not," and asked Crowley to identify himself. ${ }^{64}$

According to the report, while Crowley was explaining he was investigating a potential break-in, Gates opened the door and asked, "[W]hy, because I'm a black man in America?" 65 Crowley says he asked Gates if anyone else was in the house and "[w]hile yelling, [Gates] told me it was none of my business and accused me of being a racist police officer." ${ }^{\text {"6 }}$ Crowley goes on to say that he explained he was responding to a report from a witness, but Gates seemed to ignore him and made a phone call. ${ }^{67}$ Crowley says he then radioed that he was at a residence "with someone who appeared to be a resident but very uncooperative." ${ }^{\circ} \mathrm{He}$ heard Gates ask the person whom Gates had called to "get the chief." ${ }^{\circ 9}$ Crowley also heard Gates telling his listener that he was dealing with

52 Contreras, supra note 17 , at A7.

53 Crowley, Incident Report, supra note 2, at 1.

${ }^{54} I d$.

55 Id.

56 See Marisol Bello, Accounts Differ in Gates Incident; Witness Denies Racial Description, USA Today, July 28, 2009, at A3 (reporting Whalen's account).

57 Crowley, Incident Report, supra note 2, at 1.

58 See Bello, supra note 56, at A3 (describing Whalen's 911 call).

59 Crowley, Incident Report, supra note 2, at 1.

${ }^{60} I d$.

61 Id. at 2.

62 Id. On the case law, see Wayne R. LaFave, Search and Seizure $§ 2.2$ (a) (4th ed. 2004) (defining plain viewing as non-search if officer is lawfully present in the area).

63 Crowley, Incident Report, supra note 2, at 2.

${ }^{64} I d$.

$65 I d$.

$66 I d$.

$67 \mathrm{Id}$.

68 Id.

$69 I d$. 
a racist police officer. ${ }^{70}$ Gates then allegedly told Crowley he "had no idea who [he] was 'messing' with and that [he] had not heard the last of it."71

Crowley asked Gates to provide photo identification. ${ }^{72}$ Gates initially refused and demanded that Crowley show him identification, but Gates later supplied a Harvard University identification card. ${ }^{73}$ Crowley radioed and requested the presence of the Harvard University Police. ${ }^{74}$ The next paragraph of the Incident Report states that Crowley was preparing to leave when Gates asked for his name. ${ }^{75}$ According to Crowley, when he started to provide his name, Gates interrupted, yelling that Crowley was a racist police officer and "leveling threats that [Gates] wasn't someone to mess with." "76 Crowley reports that Gates asked for his name a third time and he said he had already provided it twice and was leaving Gates's home, so, if he had questions, Crowley would speak with him outside. ${ }^{77}$

Next, Crowley reports that as he exited the front door he heard Gates yelling another request for his name. ${ }^{78}$ Crowley again told Gates he would speak with him outside. ${ }^{79}$ According to Crowley, "My reason for wanting to leave the residence was that Gates was yelling very loud and the acoustics of the kitchen and foyer were making it difficult for me to transmit pertinent information to ECC or other responding units." 80 Crowley reports that as he left the porch, he saw several officers assembled and at least seven civilians gawking at the scene. ${ }^{81}$ Crowley further reports that as he was leaving, Gates was yelling at him, calling him a racist, and saying he had not heard the last of Gates. ${ }^{82}$

Crowley's language then mirrors the case law on arrests for disorderly conduct, which requires tumultuous behavior in front of onlookers: ${ }^{83}$

Due to the tumultuous manner Gates had exhibited in his residence as well as his continued tumultuous behavior outside the residence, in view of the public, I warned Gates that he was becoming disorderly. Gates ignored my warning and continued to yell, which drew the attention of both the police officers and citizens, who appeared surprised and alarmed by Gates's outburst. For a second time I warned Gates to calm down ... . Gates again ignored my warning and continued to yell at me. It was at this time that I informed Gates that he was under arrest. ${ }^{84}$

According to Crowley's report, Gates protested that he could not walk without his cane and that the handcuffs were too tight, whereupon Crowley procured

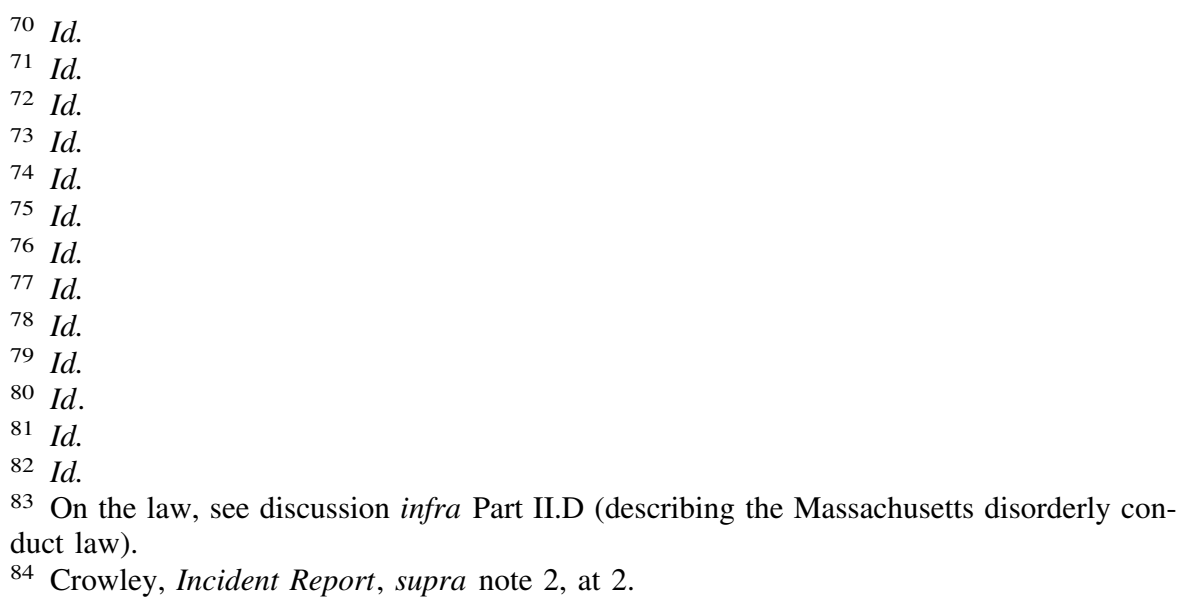


Gates's cane and had him handcuffed from the front rather than the back. ${ }^{85}$ Crowley also conferred with Gates about securing his home. ${ }^{86}$

In an Incident Supplement report, Officer Carlos Figueroa corroborates some of Crowley's report by saying of Gates, "The gentleman was shouting out to the Sgt. that the Sgt. was a racist and yelling that [']THIS IS WHAT HAPPENS TO BLACK MEN IN AMERICA![']"87 He further reports that while Gates was on the porch, he was shouting to about seven onlookers. ${ }^{88}$

\section{B. Gates's View}

For Gates, the event begins quite differently and has a very different tenor. He had just returned from China. ${ }^{89}$ With the help of his driver, he had forced open the door of his house, which had been jammed. ${ }^{90}$ He says he was already on the phone with the Harvard Real Estate Office about this problem when Crowley came onto his porch. ${ }^{91}$ Gates further says that when he opened the door to see why a police officer was on his porch, Crowley immediately asked him to step outside. ${ }^{92}$ Gates says that he instead remained in his home and asked Crowley why he was there. When Crowley told Gates he was investigating a 911 call about a breaking and entering, Gates said he lived there and was on Harvard's faculty. ${ }^{93}$ According to Gates, Crowley demanded proof of those facts. ${ }^{94}$ When Gates turned to walk into his kitchen where he had left his wallet, Crowley followed him into the house. ${ }^{95}$ Gates says he then handed Crowley both his state and Harvard identification cards. ${ }^{96}$

According to Gates, he made at least three requests for Crowley's name and badge number. ${ }^{97}$ Crowley did not respond to these requests. ${ }^{98}$ Gates says he then told Crowley, "You're not responding because I'm a black man, and you're a white officer." 99 According to Gates, Crowley's only response was to turn and walk out of Gates's house. ${ }^{100}$ When Gates followed Crowley to his front door, he was surprised to see additional police officers on his front porch. ${ }^{101}$ Gates then asked one of Crowley's fellow officers for Crowley's

$85 I d$.

86 Id.

87 Figueroa, Incident Supplement, supra note 18.

88 Id.

89 Abby Goodnough, Harvard Professor Jailed; Officer Is Accused of Bias, N.Y. TIMES, July 21, 2009, at A13.

$90 \mathrm{Id}$.

91 Charles Ogletree, Lawyer's Statement on the Arrest of Henry Luis Gates Jr., THE Root (July 20, 2009, 7:26 PM), http://www.theroot.com/views/lawyers-statementarrest-henry-luisgates-jr [hereinafter Ogletree, Lawyer's Statement].

$92 I d$.

93 Id.

94 Id.

$95 I d$.

96 Id.

97 Id.

98 Id.

99 Dayo Olopade, Skip Gates Speaks, The Root (July 21, 2009, 5:34 PM), http://www.the root.com/views/skip-gates-speaks?page $=0,0$.

100 Ogletree, Lawyer's Statement, supra note 91.

101 Id. 
name and badge number. ${ }^{102}$ When Gates stepped onto his front porch, Crowley handcuffed him. ${ }^{103}$

Gates specifically refutes Crowley's story in two ways. First, he claims he never explicitly called Crowley racist. ${ }^{104}$ As evidence that he does not "walk around calling white people racist," Gates points out that he is half-white, was married to a white woman, and has children who are part-white. ${ }^{105}$ Second, he says he could not have been particularly loud because he was recovering from a bronchial infection. ${ }^{106}$

\section{Obama's Comment and the "Beer Summit"}

As Crowley's arrest of Gates was becoming a national controversy, President Obama held a rare news conference during primetime in order to promote national healthcare. During the press conference, a reporter asked Obama what he thought of the arrest. Obama responded as follows:

Now, I don't know, not having been there and not seeing all the facts, what role race played. But I think it's fair to say, number one, any of us would be pretty angry, number two, that the Cambridge police acted stupidly in arresting somebody when there was already proof that they were in their own home, and, number three, what I think we know separate and apart from this incident is that there's a long history in this country of African-Americans and Latinos being stopped by law enforcement disproportionately. . . . That's just a fact. ${ }^{107}$

The media instantly boiled the three-part answer down to headlines about Obama's choice of the words the "Cambridge police acted stupidly."108 Cambridge Police Commissioner Robert Haas took offense, saying, "It deeply hurts the pride of this agency." 109 Nationally, police unions were critical of Obama and demanded an apology. ${ }^{110}$ Republicans pounced on the issue as a means of criticizing both Obama and Massachusetts elected officials. ${ }^{11}$

In the wake of this criticism, Obama declared he was surprised by the controversy over his statement. ${ }^{112}$ His response was to simultaneously backpedal from and justify his comments. His spokesman, Robert Gibbs, said Obama wanted to clarify that he was not calling Crowley stupid. ${ }^{113}$ Obama himself said he thought "it was a pretty straightforward commentary that you probably don't need to handcuff a guy, a middle-aged man who uses a cane, who is in his own home." 114 Obama went on to say he had "extraordinary

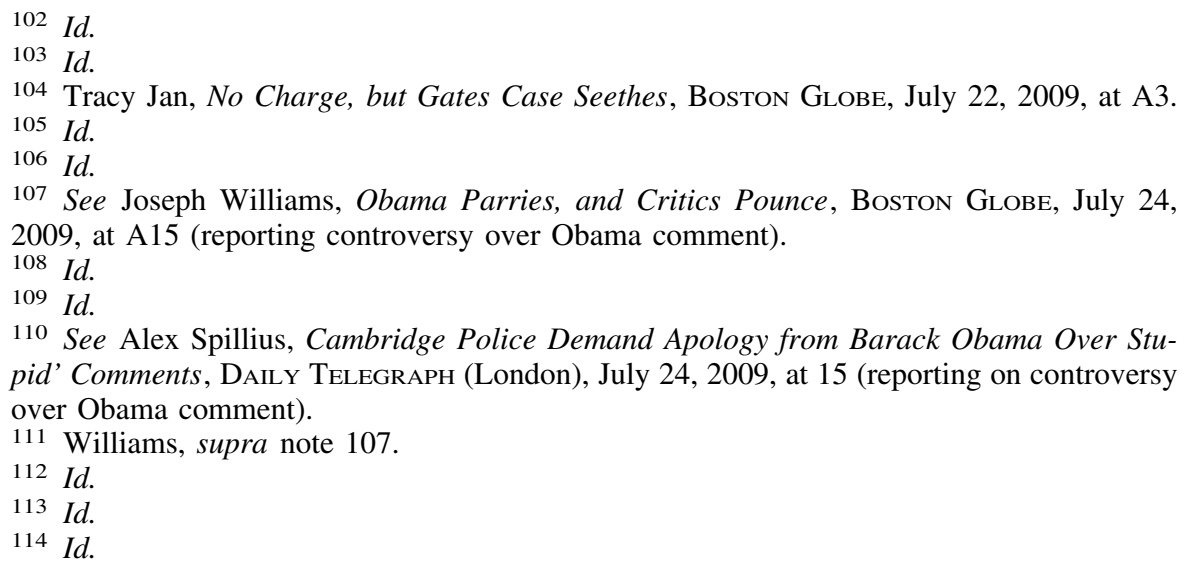


respect" for police work and he understood that Crowley was an "outstanding" officer. ${ }^{115}$

Meanwhile, Obama suffered a significant drop in his poll numbers. ${ }^{116}$ The relationship between Obama's "stupidly" comment and white flight from supporting him seems obvious from news reports:

The president's approval ratings fell, especially among working-class whites, as the focus of the Gates story shifted from details about the incident to Obama's remarks, the poll said. Among whites in general, more disapprove than approve of his comments by a two-to-one margin. ${ }^{117}$

Whites, especially working-class whites, sided with Crowley and against Gates and Obama, and Obama paid a heavy price for his comments in the polls.

The controversy appeared unresolvable until Obama invited the parties to the White House to discuss the event. ${ }^{118}$ The event was quickly dubbed the "beer summit" based on the idea that the three men would talk over a beer. ${ }^{119}$ The media read Obama's invitation of Crowley and Gates to the White House for a beer as an attempt to quell the controversy. ${ }^{120}$ Obama seemed to characterize the meeting as a mediation session, saying, "My sense is you've got two good people in a circumstance in which neither of them were able to resolve the incident in a way that it should have been resolved." 121 In the end, the summit had the desired effect of putting the controversy to rest with a dénouement wherein the media concentrated on what beers the men would choose. ${ }^{122}$

\section{The Discretion Inherent in the Massachusetts Disorderly Conduct Law}

One potential objection to the argument that Crowley's arrest of Gates was brought about by the way in which identities came together in this context is that this was simply a matter of a man being disorderly. That is, one could argue Crowley's actions were dictated by the law. This seems unlikely because the disorderly conduct law in question is so vague that it could be applied much more frequently than it actually is applied. ${ }^{123}$ If the disorderly conduct law were applied in all cases where there was probable cause of a violation, one could assume many more people would be arrested for disorderly conduct. That not being the case, we have to assume that police exercise their discretion to avoid making arrests under the disorderly conduct law.

The Massachusetts disorderly conduct law provides as follows:

115 Id.

116 See Philip Elliott, Obama's Rating Slips With White Americans, StAR-Ledger (Newark), July 31, 2009, at 3 (declaring that Obama's white support has declined, seemingly because of Gates affair).

117 Id.

118 Benac, supra note 20, at 3.

119 See Dana Milbank, It Wasn't One for the Guinness Book, WAsh. Post, July 31, 2009, at A2 (using label).

120 See Benac, supra note 20, at 3 (characterizing Obama as seeking to tamp-down controversy).

121 Id.

122 See, e.g., Millbank, supra note 119, at A2 (lamenting the beer summit as insubstantial).

123 See Commonwealth v. LePore, 666 N.E.2d 152, 155 (Mass. App. Ct. 1996) (construing requirements). 
(a) Common night walkers, common street walkers, both male and female, persons who with offensive and disorderly acts or language accost or annoy persons of the opposite sex, lewd, wanton and lascivious persons in speech or behavior, keepers of noisy and disorderly houses, and persons guilty of indecent exposure shall be punished by imprisonment in a jail or house of correction for not more than 6 months, or by a fine of not more than $\$ 200$, or by both such fine and imprisonment.

(b) Disorderly persons and disturbers of the peace, for the first offense, shall be punished by a fine of not more than $\$ 150$. On a second or subsequent offense, such person shall be punished by imprisonment in a jail or house of correction for not more than 6 months, or by a fine of not more than $\$ 200$, or by both such fine and imprisonment. $^{124}$

This language is obviously very broad. It should come as no surprise Crowley could believe he had probable cause to make an arrest on this basis.

Perhaps because of the expansive scope of the statute's coverage, the Massachusetts Supreme Judicial Court has narrowed the scope of its application. For a variety of public disturbance codes, the Court defines "disorderly" as requiring some degree of purposeful or reckless mens rea. ${ }^{125}$ In light of that construction, standard jury instructions divide the offense into three elements. First, the Commonwealth must prove the defendant committed at least one of the following actions: he either engaged in fighting or threatening; engaged in violent or tumultuous behavior; or created a hazardous or physically offensive condition by an act that served no legitimate purpose. ${ }^{126}$ Second, the Commonwealth must prove the defendant's actions were reasonably likely to affect the public. ${ }^{127}$ Third, the Commonwealth must prove the defendant either intended to cause public inconvenience, annoyance, or alarm, or recklessly created a risk of public inconvenience, annoyance, or alarm. ${ }^{128}$

It now becomes clear why Crowley used the word tumultuous to describe Gates's conduct. Gates did not engage in fighting, threatening, or violent behavior. Nor did he create a hazardous or physically offensive condition. Therefore, in order to charge Gates with disorderly conduct, Crowley had to describe Gates's actions as "tumultuous."

It is possible that the definition of disorderly conduct also drove Crowley to lure Gates onto the porch. The definition mandates that the defendant act with purpose to cause a public inconvenience, annoyance, or alarm, or recklessly create risk thereof. ${ }^{129}$ By its very definition, an individual's home is not a public place. By remaining inside his home, it would have been difficult for Crowley to contend that Gates purposely or recklessly acted to cause a public inconvenience, annoyance, or alarm. Thus, Crowley might have brought Gates to his porch so that he could charge him with disorderly conduct within the meaning of the statute.

124 Mass. Gen. Laws. Ann. ch. 272, § 53 (West Supp. 2010).

125 LePore, 666 N.E.2d at 155.

126 Mass. Continuing Legal Educ., Inc., Disorderly Conduct, in 2 Criminal Model Jury Instructions for USE IN THE District Court instruction 7.160 (2009).

127 Id.

128 Id.

129 LePore, 666 N.E.2d at 155. 
But this legal analysis fails to explain why Crowley chose to arrest Gates. The statute, even as narrowed, grants officers broad discretion to make arrests. Many police interactions will allow such an arrest. But there has been no public outcry over the statute that would suggest such arrests are made nearly as often as they could be. It seems that officers often exercise their discretion not to use this tool. Gates's behavior alone cannot explain Crowley's decision to use this law to make an arrest. In light of the extensive literature on how officers use race to determine how to use their discretion, this Article next considers how identities played a role in Crowley's decision to arrest Gates for disorderly conduct. ${ }^{130}$

\section{E. The Cambridge Review Committee's Report}

Amid the controversy over Crowley's arrest of Gates, Cambridge Police Commissioner Robert Haas requested a study to identify lessons to be learned from the situation. ${ }^{131}$ The twelve-person committee consisted of several law enforcement officials, scholars, and a civilian. ${ }^{132}$ The Committee's eventual report, Missed Opportunities, Shared Responsibilities, begins by concluding that Crowley and Gates "each missed opportunities to 'ratchet down' the situation and end it peacefully." 133 According to the Committee, "[T]he incident was sparked by misunderstandings and failed communications between the two men."134 The misunderstandings stemmed from the fact the men were each fearful of the other. ${ }^{135}$ Crowley felt he was entering "an unknown and potentially dangerous situation," while Gates was wary of police. ${ }^{136}$ According to the Committee, the men should not have been fearful after Crowley explained his presence and Gates showed his identification. ${ }^{137}$ "[T] he behavior of both men should have begun to change," the Committee found, but "both men continued to escalate the encounter." 138

The Committee's "shared responsibilities" conclusion seems to stem from its perception that there was a mutual escalation of the incident. It says, "Crowley could have taken greater pains to explain the uncertainty and potential dangers of responding to a serious crime-in-progress call." ${ }^{139}$ At the same time, though, "[Gates] could have tried to understand the situation from the point of view of a police officer responding to a 911 call about a break-in in progress, and could have spoken respectfully to Sergeant Crowley and accommodated his request to step outside at the beginning of the encounter." 140 The

130 See generally Frank Rudy Cooper, Cultural Context Matters: Terry's "Seesaw Effect", 56 OKLA. L. Rev. 833, 833 (2003) (arguing police discretion to make stops and frisks is likely to lead to over- and under-policing); see also Thompson, supra note 19, at 983-87 (arguing stereotypes lead to heightened suspicion of racial minorities).

131 Missed Opportunities, supra note 22, at 1.

132 Id. at 2.

$133 \mathrm{Id}$. at 3.

134 Id.

135 Id.

136 Id.

137 Id.

138 Id.

139 Id.

140 Id. at 3-4. 
Committee goes on to cite Crowley and another officer for the proposition that Gates was not listening and Gates for the proposition that Crowley was unresponsive. ${ }^{141}$

Most importantly, the report argues that officers and civilians have shared responsibilities for keeping the peace. It says that episodes such as the Gates incident result when the parties "do not share a sense of responsibility about cooperating toward the common goal of a positive encounter that results in increased public safety." ${ }^{142}$ Its proposal is basically that civilians and officers must share responsibility for the public safety: "If each police officer and each member of the community can think in terms of sharing responsibility for showing one another respect and understanding, the entire functioning of a police department will improve."143

\section{The Arrest as a Masculinity Contest}

Some might suggest that Crowley arrested Gates solely because of his attitude. That would make this a so-called "attitude arrest."144 Similarly, Crowley may have arrested Gates because of the "asshole factor" created by his lack of cooperation. ${ }^{145}$ Although judges have an official power to sanction people for contempt of court, there seems to be an unofficial rule that police officers may arrest someone for "contempt of cop."146 But to say Gates was arrested for his attitude begs important questions regarding what, precisely, about Gates's attitude prompted his arrest: Would a similarly situated white man have been arrested? Would a similarly situated black woman have been arrested? ${ }^{147}$

141 Id. at 4.

142 Id.

143 Id.

144 See Kel Munger, “Attitude Arrests" and Other Bad Cops Secrets, SNOG (July 7, 2009, 4:14 PM), http://www.newsreview.com/sacramento/snog/blogs/post?oid=1043726 (arguing Gates's attitude combined with race to cause arrest).

145 My colleagues Diane Juliar and Ann McGonigle Santos point out that prosecutors are aware that police sometime arrest people simply for being obnoxious and then leave it to the prosecutor to sort out details.

146 See Clarence Page, Gates-gate: A Clear Case of 'Contempt of Cop', CHI. Trib., July 26, 2009, at C27 (describing the Gates arrest as for "contempt of cop").

147 Another question for a multidimensional analysis of the arrest, which is beyond the scope of this Article, is did Crowley and Gates's class statuses influence the event? The short answer is that they must have influenced the arrest. The class analysis starts by noting Crowley's working-class status. Policemen are generally considered working-class despite their above-average incomes because the job is identified with the working-class. See Michelle Fine et al., (In) Secure Times: Constructing White Working-class Masculinities in the Late 20th Century, 11 GENDER \& Soc'y 52, 61 (1997) (noting white male resentment of black men's entry into police departments). Growing up going to the public schools in Cambridge, Crowley would have been considered a "townie" by the many university-affiliated students and staff. There is certainly a "Town/Gown" split in Cambridge. See Morning Edition: Cold Beer Could Tamp Down Uproar Over Arrest (National Public Radio broadcast July 29, 2009), available at http://www.npr.org/templates/story/story.php?storyId=1112732 $91 \& \mathrm{ft}=1 \& \mathrm{f}=1015$ (Juan Williams speculating Gates's arrest was the result of town/gown split). As a resident of Cambridge, the author does observe such a split, but doubts it is so great as to cause an arrest all by itself. Further, the area Crowley grew up in is considered largely working-class compared to the upper-class neighborhoods of Harvard Square, Porter 
Sociologist and legal scholar Bernard Harcourt provides a succinct answer to the first of those questions. He says, "Without doubt, the issue of racial profiling infected the encounter between Sergeant Crowley and Professor Gates." 148 Specifically,

[I]t is hard to imagine that Sergeant Crowley would have arrested a white Harvard professor of equal stature or status .... At each minute juncture of the encounter, might there have been a difference-say, in the way the Sergeant introduced himself, asked for identification, responded to the challenge, positioned his body, or looked at Professor Gates?" 149

In other words, Crowley need not be explicitly racist to have believed the pervasive stereotype of black men being dangerous. ${ }^{150}$ One needs only a cursory look at the extensive literature on implicit bias to see that even a well-meaning police officer is likely to have an anti-black bias that will influence his behavior. ${ }^{151}$

So, would this incident have played out differently if Gates had been white? Of course. As Harcourt notes, race implicitly influences every juncture of the interaction between a white police officer and a black suspect. ${ }^{152}$ At the very least, the parties were influenced by the fact that their races made it readily believable that Crowley was racially profiling Gates. As Harcourt writes,

Square, or West Cambridge. See Krissah Thompson \& Cheryl W. Thompson, Officer Tells His Side of The Story in Gates Arrest, WAsh. Post, July 24, 2009, at A1 (identifying Crowley as growing-up in a primarily Irish-Catholic neighborhood). No disrespect to workingclass neighborhoods: The author grew up in, and is currently a resident of, a mixed-income neighborhood in Cambridge.

Crowley's working-class status created a sharp contrast between him and Gates. Gates is not only professional class, but a member of the privileged intelligencia. See Eugene Kane, Racial Issues Still Simmer on Front Burner, Journal Sentinel (Milwaukee), Aug. 4, 2009, at B1 (discussing Gates's privilege). The prestige of Gates's status as a Harvard professor is obvious. Crowley's consciousness of Gates's class status (even if only at a subconscious level) was potentially primed by Gates telling Crowley he did not know who he was messing with. See Crowley, Incident Report, supra note 2, at 2 (asserting Gates said that Crowley "had no idea who [he] was 'messing' with"). That statement implied that Gates was a big shot and Crowley a small-fry. We might expect the general resentment of black males that is sometimes held by working class white status, as primed by Gates's class-based insult, to make Crowley more likely to arrest Gates. See generally Fine et al., supra (analyzing white working-class men's translation of economic duress into racial resentment); Michael S. Kimmel, Masculinity as Homophobia: Fear, Shame, and Silence in the Construction of Gender Identity, in The Gender of Desire: Essays on Male SexualITY 25, 38 (Michael S. Kimmel ed., 2005) (describing denigration of racial minority men and other contrast figures as part of hegemonic masculinity).

148 Bernard Harcourt, Henry Louis Gates and Racial Profiling: What's the Problem? 6 (John M. Olin Law \& Econ., Working Paper No. 482, 2009), available at http://ssrn.com/ abstract $=1474809$.

${ }^{149} I d$. at 6-7. Harcourt does qualify this conclusion, saying things like, "However, it is also hard to believe that [a white professor] would have protested the police presence and questioning so vehemently - and in that sense, again, it is impossible to extricate race from the encounter, on both sides of the incident." Id. at 6 (emphasis in original).

150 See, e.g., Cooper, Against Bipolar Black Masculinity, supra note 25, at 877-78 (detailing criminality component of Bad Black Man image).

151 See, e.g., Harcourt, supra note 148, at 6, 26 n.26 (citing articles).

152 See generally L. Song Richardson, Arrest Efficiency and the Fourth Amendment, Minn. L. Rev. (forthcoming) (arguing implicit bias helps explain police officers' exercises of their discretion), available at http://papers.ssrn.com/sol3/papers.cfm?abstract_id=1625755. 
"It is clear that Professor Gates believed that he was being profiled. It is also clear that Sergeant Crowley understood that he was being accused of racial profiling." 153

A preliminary answer to the question of whether Crowley would have arrested a similarly situated woman is "no." The fact that Crowley and Gates are both men created a greater likelihood the parties would not back down from their positions. By reviewing the field of masculinities studies as applied to policing, one can demonstrate that the parties challenged each other's masculinities.

\section{A. Masculinities Studies Methodology and Policing}

To say masculine esteem was in play for the parties is to imply people can lack internal and/or attributed masculine esteem. ${ }^{154}$ Usually, those people are men, but women can adopt masculine modes of behavior, ${ }^{155}$ as when their success in male-dominated fields depends on taking "manly" actions. ${ }^{156}$ The field of masculinities studies looks at the messages U.S. culture sends about how to be manly, and thereby reveals ways in which both cultural institutions and individual behaviors are the product of the hegemonic, or dominant, norms of masculinity. ${ }^{157}$ Applying masculinities studies to policing reveals that the need to boost masculine esteem can greatly influence officer and suspect behaviors.

\section{The Hegemonic Pattern of U.S. Masculinity}

To begin the process of applying masculinities studies to the Gates arrest, it will be helpful to identify the hegemonic, or dominant, pattern of U.S. masculinity. ${ }^{158}$ Doing so will demonstrate how masculinity generally operates. A

153 Harcourt, supra note 148, at 7 (emphasis in original).

154 Masculine esteem is the perception, which can be internal or external, that a person satisfies the social norms for manliness that operate in a particular context. See generally Cooper, Who's the Man?, supra note 13 (defining masculinities studies and applying it to police officer behaviors).

155 See, e.g., Frank Rudy Cooper, Our First Unisex President?: Black Masculinity and Obama's Feminine Side, 86 Denv. U. L. REv. 633, 634-35 (2009) (warning of need to think carefully about what is masculine or feminine).

156 As a simple example, consider the masculinist tenor of law. See generally LaNI Guinier et al., Becoming Gentlemen: Women, Law School, and Institutional Change (1997) (documenting masculinist assumptions of law training).

157 See Bederman, supra note 30, at 7 (defining masculinities studies). This Article departs slightly from the predominant "hegemonic masculinities" school of masculinities studies and instead adopts a "multidimensional masculinities" approach. See generally MAsCULINITIES AND LAW, supra note 30 (collecting essays utilizing a multidimensional masculinities approach). Multidimensionality theory is a concept from critical race theory of law. It says that categories of identity operate simultaneously and create different effects in different contexts. See, e.g., Hutchinson, "Gay Rights" for "Gay Whites?", supra note 25, at 1362-68 (defining the multidimensionality theory). For example, both a heterosexual black man's sense of self identity and the ways that he is treated differ from the self identities and treatment of gay black men. Meanwhile, heterosexual black men are likely to think of themselves differently and be treated differently in a sports bar versus an art gallery. Merging hegemonic masculinities theory and multidimensionality theory creates a multidimensional masculinities approach.

158 "Hegemonic" masculinity is the definition of manhood that is dominant in a given cultural context. See R.W. Connell \& James W. Messerschmidt, Hegemonic Masculinity: 
good starting point is to consider the competitiveness and anxiety common to all forms of masculinities.

Pioneering masculinities theorist Michael Kimmel says that men are engaged in "homosocial" competition. ${ }^{159}$ Homosocial competition is that which occurs between men. ${ }^{160}$ As Kimmel theorizes, what appears to be men showing off for women is really men showing off for men. ${ }^{161}$ Men collect evidence of success-money, power, women-to show other men they are manly. ${ }^{162}$ According to Kimmel, "We test ourselves, perform heroic feats, take enormous risks, all because we want other men to grant us our manhood."163 Kimmel places the roots of this desire to attain the approval of other men in a Freudian analysis of childhood. Kimmel claims that boys start out connected to their mothers, but then come to identify with their fathers, and therefore seek to distinguish themselves from women. ${ }^{164}$ Although Freud's model of sexual development has been challenged, ${ }^{165}$ there is some logic to the idea that a boy would believe that to affirm his status as a man, he must get the approval of other men. If that is so, masculine self-esteem will require the affirmation of other men.

This need for the affirmation of others makes masculinity fundamentally anxious. Men tend to grant affirmation of masculinity when they see behaviors they already associate with masculinity. ${ }^{166}$ Manhood is thus a never-ending test of whether one's behaviors measure up to the ideal form of manhood. ${ }^{167}$ But the rules of the hegemonic form of U.S. masculinity-(1) denigrate contrast figures, such as women, (2) accrue tokens of success, (3) hold one's emotions in check, and (4) be aggressive ${ }^{168}$-are unrealizable. ${ }^{169}$ It is difficult, if not impossible, for any man to embody these characteristics of the ideal man at every given moment and over the course of his lifetime. Men are always subject to being "unmask[ed]" as less than manly. ${ }^{170}$ The need to prove masculinity is thus a constant source of anxiety.

The role of the denigration of contrast figures deserves further elaboration. The idea is that men have often identified other groups of men from whom they

Rethinking the Concept, 19 GENDER \& SoC'y 829, 846 (2005) ("The fundamental feature of the concept [of hegemonic masculinity] remains the combination of the plurality of masculinities and the hierarchy of masculinities.").

159 KIMMEL, supra note 147, at 33.

160 See Eve Kosofsky Sedgwick, Between Men: English Literature and Male Homosocial Desire 1 (1985) (defining homosocial).

161 KIMMEL, supra note 147, at 33.

162 Id.

163 Id.

$164 I d$. at 31-32.

165 See generally Juliet Mitchell \& Sanjay Mishra, Psychoanalysis and Feminism: A Radical Reassessment of Freudian Psychoanalysis (Basic Books 2000) (1974) (critiquing Freud).

166 See Cooper, Who's the Man?, supra note 13, at 684 (identifying existing social norms as source of judgments that one is or is not manly).

167 See Kimmel, supra note 147 , at 31 (describing relentlessness of homosocial male competition).

168 Id. at $30-31$.

$169 \mathrm{Id}$. at 31.

170 Id. at 36. 
distinguish themselves. ${ }^{171}$ Gay men, racial minorities, Jews, and women have served as contrast figures for the historically dominant straight, white, Christian male. ${ }^{172}$ The denigration of these figures has allowed dominant men to bolster their masculine esteem. ${ }^{173}$ As criminologist James Messerschmidt has discussed, there is a long history of police harassment of black and gay men. ${ }^{174}$ That history is related to the bolstering of the officer's masculine esteem. ${ }^{175}$ For now, it suffices to say homosocial competition and anxiety are structured into masculinity and lead to the denigration of contrast figures.

\section{The Hegemonic Pattern of Police Masculinity}

A core aspect of the hegemonic pattern of police officer identity, as distinguished from the hegemonic pattern of U.S. masculinity in general, is the officer's sense he must enact a command presence. One has command presence when one takes charge of a situation. ${ }^{176}$ The officer projects confidence and decisiveness. ${ }^{177}$ Command presence is also associated with the physical control of suspects. It is justified by the need to control dangerous suspects. ${ }^{178}$ When misused, it can amount to police brutality. ${ }^{179}$ As has been demonstrated elsewhere, seeing the enactment of command presence as the core of the job is a characteristic of policing throughout the country. ${ }^{180}$

A corollary of the fact that police officers' senses of self are tied up with their ability to enact command presence is an unwritten rule that civilians must show deference to the badge. ${ }^{181}$ That attitude has its roots in what sociologists Dov Cohen and Joe Vandello call the culture of honor. ${ }^{182}$ In a culture of honor,

171 Id. at 38 .

172 Id.

173 See id. (noting groups use "others" to contrast their conception of masculinity).

174 See James W. Messerschmidt, Masculinities and Crime: Critique and ReconcepTUALIZATION OF THEORY 184 (1993) (linking racial profiling and homophobia to police officer masculinity). See generally Tracey Maclin, Terry v. Ohio's Fourth Amendment Legacy: Black Men and Police Discretion, 72 St. John's L. Rev. 1271 (1998) (detailing widespread police harassment of racial minority men); David Alan Sklansky, "One Train May Hide Another": Katz, Stonewall, and the Secret Subtext of Criminal Procedure, 41 U.C. DAvis L. Rev. 875 (2008) (identifying gay-bashing as a central feature of 1950s and 1960s policing).

175 See Messerschmidt, supra note 174, at 184 (referencing this history).

176 Mary Newman, Comment, Barnes v. City of Cincinnati: Command Presence, Gender Bias, and Problems of Police Aggression, 29 HARv. J.L. \& GENDER 485, 491 (2006) (quoting Erwin Chemerinsky, An Independent Analysis of the Los Angeles Police Department's Board of Inquiry Report on the Rampart Scandal, 34 Loy. L.A. L. REV. 545, 563 (2001) (linking command presence to aggression)).

177 Id. at 487 (defining term).

178 See id. at 491 (quoting Chemerinsky, supra note 176, at 563) (describing command presence)).

179 See id. (blaming command presence for excessive force).

180 See generally Cooper, Who's the Man?, supra note 13 (detailing the hegemonic pattern of police officer masculinity); Newman, supra note 176 (associating command presence with policing in general).

181 See Cooper, Who's the Man?, supra note 13, at 697-98 (describing punishment of disrespect as part of the hegemonic pattern of police officer masculinity).

182 See generally Dov Cohen \& Joe Vandello, Meanings of Violence, 27 J. Legal STud. 567 (1998) (describing how cultures of honor operate). 
one must protect one's social stature or suffer being taken advantage of. ${ }^{183}$ For instance, herdsmen often cannot keep an eye on every member of their roving flocks. ${ }^{184}$ To discourage poaching, they must have a reputation for punishing anyone who messes with their flocks. ${ }^{185}$ Accordingly, protecting one's honor becomes paramount and insults are treated as grave threats to one's identity and livelihood. ${ }^{186}$

Police officers seem to fear that if they let an instance of disrespect pass, they will be subject to constant challenges. ${ }^{187}$ Because officers feel they might need to impose command presence on a situation at any moment, they often feel they must constantly enforce a rule of deference to the badge. ${ }^{188}$ Police officers are often on the lookout for any sign of disrespect of their authority, which they will then punish in varying degrees. ${ }^{189}$

The rule of deference to the badge should be linked to masculinity because police officers associate their police authority with their masculine authority. As early as 1970, sociologist James F. Scott concluded that "to make depreciatory remarks about the police role is to cast aspersion upon the policemen's conceptions of themselves as men." 190 As late as 1999, criminologist Susan Ehrlich Martin determined that "[s]ince a key element of policing—gaining and maintaining control of situations-remains associated with manhood, male officers do gender along with doing dominance."191 Both of these scholars suggest police officers conflate their masculine authority and their police authority. What seems to be the product of their roles-the rule of deference to the badge - is also a product of gender identity. This is made obvious by the fact that jobs are often gendered; nurses are stereotypically female and police officers are paradigmatically male. Thus, it is no surprise police officers often use their roles to boost their individual masculine esteem.

\section{Police as Incentivized to Initiate Masculinity Contests}

Having seen that men generally suffer from masculine anxiety and that police officers often express such anxiety through the rule of deference to the badge, it is important to consider the possible results of this situation. In doing so, it will be helpful to define and apply the theory of masculinity contests, which are among the common results. This theory emerges from, but also distinguishes itself from, Messerschmidt's theory of the "masculinity challenge."

One's masculinity is challenged when one is threatened or expectations of masculine behavior are unachievable. ${ }^{192}$ One's manhood is obviously

\footnotetext{
183 Id. at $569-70$.

$184 \mathrm{Id}$. at 570.

185 Id.

186 Id.

187 Cf. Harris, supra note 30, at 798 (discussing roots of police brutality).

188 See Cooper, Who's the Man?, supra note 13, at 693-98 (linking command presence and punishing disrespect).

189 See id. at 697 (discussing punishing disrespect).

190 James F. Scott, Racial Group Membership, Role Orientation, and Police Conduct Among Urban Policemen, 31 Phylon 5, 12 (1970).

191 Susan Ehrlich Martin, Police Force or Police Service? Gender and Emotional Labor, 561 Annals Am. Acad. Pol. \& Soc. Sci. 111, 117 (1999).

192 Messerschmidt, Becoming Real Men, supra note 31, at 298.
} 
threatened, for example, when he is challenged to a fight. ${ }^{193}$ The challenge is in being put in the position of having to either back down and appear less manly, or fight and risk harm or other consequences. Men also have their masculinity challenged when the manly way of acting is hard to achieve. ${ }^{194} \mathrm{~A}$ prime example of this is when men are expected to act unemotional in the face of tragedy. The challenge is to either let their grief show and be perceived as unmanly, or be stoic and risk harming themselves emotionally. When men find their masculinities challenged, they often seek ways to boost their masculine self-esteem. ${ }^{195}$ One way to do so is to initiate a masculinity contest.

A masculinity challenge ripens into a masculinity contest when two or more people are subject to a masculinity challenge, although only one person or one side will be able to boost its internal or attributed masculine esteem. ${ }^{196} \mathrm{~A}$ masculinity contest is thus inter-relational; it arises from the conflicts between two or more people. It is also a zero-sum game; for someone to win, someone must lose.

When someone issues a challenge to a fight, he creates a masculinity contest because he has challenged the masculinity of the other as noted above. However, he is also under a masculinity challenge. If the other fights, the initiator will now have his masculinity judged based on his performance. As it is put in the movie Mad Max Beyond Thunderdome, "Two men enter, one man leaves." 197 In the movie, that quote described a fight to the death. ${ }^{198}$ Usually, a masculinity contest involves only a figurative harm to one's internal or attributed masculine esteem. While there are nuances to what constitutes "winning" a fight that affect one's internal and attributed masculine esteem, masculinity is clearly at stake in a masculinity contest.

There are some differences between a masculinity challenge and a masculinity contest that bear mentioning. First, a masculinity challenge is something experienced by an individual, whereas a masculinity contest requires multiple people. Second, a masculinity challenge is felt internally, but a masculinity contest is inter-subjective, and thus a shared experience. Third, a masculinity challenge can be resolved without harming another, but a masculinity contest is a zero-sum game that must be resolved at another party's expense. It is possible, of course, for both parties to back down simultaneously, but then it would cease to be a masculinity contest altogether.

Why might a police officer initiate a masculinity contest in response to a masculinity challenge? The literature of class and masculinities introduces the concept of "compensatory subordination" to describe men's reactions to being of low status in an environment. ${ }^{199}$ For example, working-class men sometimes compensate for their low status along one axis of identity by subordinat-

193 Cooper, Who's the Man?, supra note 13, at 698.

194 Messerschmidt, Becoming Real Men, supra note 31, at 298.

195 See id. at 303.

196 See Cooper, Who's the Man?, supra note 13, at 698-701 (defining masculinity contest).

197 Mad Max Beyond Thunderdome (Warner Bros. 1985) (depicting fight).

198 Id.

199 See Karen D. Pyke, Class-based Masculinities: The Interdependence of Gender, Class, and Interpersonal Power, 10 GENDER \& SoC'y 527, 531-32 (1996) (defining compensatory subordination). 
ing others who are below them along other axes. ${ }^{200}$ Thus, the guys on the oil rig might harass the co-worker they consider gay and working-class men might be more likely to engage in domestic abuse. ${ }^{201}$

James Messerschmidt argues that police officers assigned to street duty seek to reinforce their masculine self-esteem through their occupational behaviors. He contends that police officers are divided into street-cop and office-cop cultures. ${ }^{202}$ "Street-cop masculinity . . . reflects, in part, street-cop desire to deny a subordinate position within hierarchical department power relations among men." 203 Whereas the hegemonic pattern of U.S. masculinity emphasizes the dominance, control, and independence characterizing office-cop positions, ${ }^{204}$ street-cops redefine their physical work as the epitome of masculinity. ${ }^{205}$

Street-cops are thus in "penalty status" because of class. Penalty status is the condition of already having something about your identity that makes your masculinity suspect. ${ }^{206}$ For example, if the idealized masculinity is heterosexual, white, and upper-middle-class (and, arguably, Christian), then men who do not fit all of those categories know their quest to measure up to the ideal is already hampered. Street-cops can respond to their penalty status by engaging in compensatory subordination (and thereby reinforcing their masculine selfesteem) by denigrating contrast figures, such as gay men, racial minority men, and lower-class men. ${ }^{207}$ Messerschmidt thus concludes that "police construct a white, heterosexual form of hegemonic masculinity through the authorized practice of controlling 'deviant' behavior of 'inferior' men."208

As applied to Crowley, Messerschmidt's work suggests Crowley's streetcop status would be expected to simultaneously emphasize his one-down status vis a vis class and provide him with a resource for compensatory subordination-the repression of deviant men. Gates's blackness would be expected to trigger this response in the form of heightened suspiciousness and a lower tolerance for uncooperative behavior. ${ }^{209}$

200 See Nancy Ehrenreich, Subordination and Symbiosis: Mechanisms of Mutual Support Between Subordination Systems, 71 UMKC L. REv. 251, 291-92 (2002) (describing compensatory subordination).

201 See id. at 292-93 (discussing possibility lower-class men are more likely to commit domestic violence).

202 Messerschmid, supra note 174, at 178.

203 Id. at 179.

204 Id. at 180.

205 See id. at 178-79. (discussing street cop masculinity).

206 See Cooper, Against Bipolar Black Masculinity, supra note 25, at 900 (arguing groups that are "one down" from the masculine norm are encouraged to exercise compensatory subordination over other groups along other axes of identity).

207 See Messerschmidt, supra note 174, at 184 (linking different forms of police repression of "deviant" men).

208 Id.

209 See Harcourt, supra note 148, at 7 (identifying that Crowley might have treated Gates differently than a similarly-situated person because of his race). Again, Crowley's sense of his working-class status may have been primed by Gates's statement that he had "no idea who [he] was messing with," which Crowley's Report emphasizes by alleging the same statement multiple times. Crowley, Incident Report, supra note 2, at 2. So, Crowley's class status was arguably a motivating factor for arresting Gates over and above the influences of Gates's behavior and the masculine esteem of both parties. 


\section{B. Crowley's Arrest of Gates as a Masculinity Contest}

The elements of Gates's arrest make it clear that masculinity was at stake for both parties. However, that is not to say race and class did not also play a role in the arrest. As becomes apparent in detailing the masculinity norms at play, those aspects of identity influenced the arrest. But unlike race and class, which have received much media attention, masculinity is a major piece of this event that has received little of the attention it deserves.

\section{Crowley Challenged Gates's Masculinity}

Crowley challenged Gates's masculinity in two primary ways. First, Crowley assumed Gates had committed a crime. Both Crowley's report and Gates's account suggest Crowley's first words to Gates insinuated that Gates had broken into the house. Crowley immediately asked Gates to leave his own house. ${ }^{210}$ This appears to have been an attempt to exercise command presence by controlling the situation. The relevant law required Crowley to obtain a warrant or Gates's consent to enter the house, so Crowley would have had more control if Gates had left his house at that time. ${ }^{211}$ Gates seems to have interpreted the request to leave his home as an assertion that something illegal was going on. ${ }^{212}$ To see why Gates might have reacted in this way, imagine an alternative means for Crowley to have initiated the encounter: he might have allowed Gates to stay in the comfort of his home and, after introducing himself and explaining his presence, requested to join Gates in the house.

Second, and related to Crowley's initial assumption of illegality was his disbelief of Gates's credentials. Almost immediately after asking Gates to exit his home, Crowley asked Gates to identify himself. When Gates said he lived in the home and was a professor at Harvard, Crowley required him to prove those facts with identification. ${ }^{213}$ Again, Gates's statement suggests he took offense at Crowley's seeming disbelief that Gates was the resident and a Harvard professor. ${ }^{214}$ To see why Gates may have taken offense at the requirement of proof, consider that Gates knew no crime had taken place. He was innocent, yet was being required to provide identification to a police officer who had little reason to believe a crime had in fact taken place.

Crowley's assumption that Gates committed a crime and disbelief of his identity was particularly likely to offend Gates in light of the historic tensions between the police and black men. Masculine anxiety might have been higher for Gates because he was in penalty status due to his race. As many masculinities theorists have noted, the idealized masculinity is white. ${ }^{215}$ As a conse-

210 Crowley, Incident Report, supra note 2, at 2.

211 See generally Vale v. Louisiana, 399 U.S. 30 (1970) (holding officers may not enter a home to arrest someone whom they have probable cause to arrest without a warrant).

212 See Ogletree, supra note 89 (implicitly criticizing Crowley's immediate request that Gates exit home).

213 Id.

214 See id. (implicitly criticizing Crowley's demand of proof of identity).

215 See, e.g., Kimmel, supra note 147, at 25, 38 (discussing qualities of idealized male). 
quence, racial-minority men have historically been viewed as either nonmasculine or all-too masculine. ${ }^{216}$

The view of blacks as all-too masculine is a source of the traditional police characterization of blacks as warranting greater suspicion ${ }^{217}$ and constituting a greater danger to officers. ${ }^{218}$ Gates probably perceived he had to live down that reputation when confronted by Crowley. Gates's immediate accusation of racism is itself a tip-off that Gates also felt his masculinity was at stake. Black men have long perceived racism to be a means of emasculating them, ${ }^{219}$ thus the 1960s civil rights placards declaring, "I am a man." 220 At least at a subconscious level, then, Gates may have felt that Crowley's purported racism was an attack on his manhood. ${ }^{221}$ Indeed, commentators have analyzed the Gates arrest in light of the history of police repression of black men. ${ }^{222}$

Moreover, Gates had two special reasons to feel Crowley was challenging his masculinity. The first invokes the commonly held belief that a man's home is his castle. Empirical research demonstrates that men are more likely to enter masculinity contests when confronted in their homes. ${ }^{223}$ Second, Gates's class privilege might have made him feel especially affronted by Crowley's behavior. Given his many academic achievements (i.e., his class status), Gates would be particularly irritated by the need to overcome stereotypes about his blackness. Gates's eventual assertion of being a bigger man than Crowley (by saying Crowley did not know who he was messing with) was a way of reasserting his manliness in the face of a perceived racial emasculation. ${ }^{224}$

216 Id. at 38; see also Cooper, Against Bipolar Black Masculinity, supra note 25, at 874-888 (discussing bifurcated image of Bad Black Man and Good Black Man).

217 See generally Thompson, supra note 19 (discussing stereotype of black criminality).

218 See Thomas L. Dumm, The New Enclosures: Racism in the Normalized Community, in ReAding Rodney King/Reading Urban Uprising 178, 182 (Robert Gooding-Williams ed., 1993) (critiquing 1980s political science linking black men's race to criminal attributes).

219 See generally Devon W. Carbado, Men in Black, in 3 J. Gender, Race \& Just. 427 (2000) (describing negative consequences of black men's attempts to respond to perceived emasculation).

220 See, e.g., Black Men on Race, Gender, and Sexuality (Devon Carbado ed., 1999) (depicting black men wearing "I am a Man" signs on cover of anthology of black men's writings).

221 To relegate Gates's masculine anxiety to the subconscious level would not be to denigrate it as superfluous, for our behaviors are often motivated by subconscious feelings. See, e.g., Charles R. Lawrence III, The Id, the Ego, and Equal Protection: Reckoning with Unconscious Racism, 39 Stan. L. REv. 317, 327 (1987) (discussing significance of unconscious racism to behavior).

222 See, e.g., Damon W. Root, Op-Ed., Blacks and Cops: A Dysfunctional Relationship, Chi. Sun Times, July 25, 2009, at 15 (referring to troubled history between police and black men); Kara Rowland \& David R. Sands, Obama Calls Officer in Bid to Calm Racial Flap, Wash. Times, July 25, 2009, at A1 (referring to troubled history between police and blacks). 223 See Cooper, Who's the Man?, supra note 13, at 699-700 (describing James Hudson's research on when civilians lodge complaints against police).

224 One might even say that Gates's assertion that he was a bigger man than Crowley was an act of compensatory subordination. Compensatory subordination occurs when people who are subordinated along one axis of identity exercise their privilege along another axis of identity to compensate themselves for their oppression. See Cooper, Against Bipolar Black Masculinity, supra note 25, at 859 (arguing bipolar representation of black men as completely Good or Bad based on assimilation leads to compensatory subordination). But it is 


\section{Gates Challenged Crowley's Masculinity}

Crowley's masculine anxiety might have been exacerbated during the Gates arrest because Crowley was in penalty status due to his class. As a street-cop, Crowley would commonly be described as working-class. That might not matter in many interactions, but it might matter when an officer is confronting a member of the cultural elite, such as a Harvard professor. The elite have much greater power to make an officer pay for a bad decision, which Gates demonstrated by getting the charges dropped and garnering international media coverage. Gates primed Crowley's consciousness of Gates's superior class status by claiming that Crowley did not know who he was "messing with."

Gates seems to have violated the rule of deference, and thereby presented Crowley with a masculinity challenge, in four basic ways: (1) by refusing Crowley's requests that Gates exit his home; (2) by demanding Crowley's name and badge number; (3) by calling Crowley racist; and (4) by suggesting that he was more important than Crowley.

\section{a. Gates's Refusal to Follow Crowley's Request to Leave His Home}

The first challenge was created by Crowley's initial request for Gates to exit his home. ${ }^{225}$ Gates replied, "No, I will not."226 When Crowley explained that he wanted to speak with Gates because he was investigating a potential break-in, Gates asked, "[W]hy, because I'm a black man in America?"227 Those initial refusals to cooperate with Crowley are crucial to understanding Crowley's subsequent actions.

There are several signs that Crowley took offense at Gates's refusal to leave his home. The first is that Crowley took this event so far as to arrest Gates even after verifying Gates's identity and determining that no break-in occurred. ${ }^{228}$ This suggests Crowley was personally offended by Gates's refusal to leave his home. A second sign that Crowley was offended by Gates's refusal to leave his home is that Crowley made multiple attempts to get Gates to leave his home. ${ }^{229}$ Crowley really wanted Gates to leave his house. At some point, that desire was connected to an intent to arrest Gates. Hence, as soon as Gates walked out onto the porch, Crowley began the process of arresting him. ${ }^{230}$

A third sign Crowley was offended by Gates's refusal is the lengths he went to in order to explain why he asked Gates to leave his home. Crowley suggested in his police report that the "acoustics" in Gates's kitchen made it hard for him to transmit information to other units. ${ }^{231}$ On its face, this seems to be a stretch. Nobody has subsequently suggested Gates's kitchen was so

not as clear that this was an act of compensatory subordination (or of subordination at all) as it is that Crowley's arrest of Gates was an act of compensatory subordination.

225 Crowley, Incident Report, supra note 2, at 2.

$226 I d$.

227 Id.

228 See id. (acknowledging confirmation of Gates's identity and residence).

229 See id. (reporting several attempts to get Gates onto the porch).

230 See id. (noting warning to Gates of potential arrest immediately upon his exiting home).

231 Id. 
cavernous as to have unusual "acoustics." Although getting Gates out of the house eventually facilitated a disorderly conduct charge by bringing Gates into the public, the initial desire to get him out of the house is based only on the flimsy "acoustics" rationale. This suggests a more likely reason for wanting Gates to exit his house was that Crowley had requested it and Gates had refused. The spurious justification of the request signifies that the request itself, not the reason for the request, was the important thing. Gates was violating the rule of deference to the badge, which Crowley might have experienced as a disrespect of his masculine standing.

Finally, Gates's refusal to leave his home heightened the masculinity challenge to Crowley because it took place in front of his police officer peers. Crowley faced a loss of masculine esteem in front of other men. Further, because police officers are especially concerned with exhibiting command presence and punishing disrespect, Crowley might have felt his peers would disapprove of his backing down. In view of the scholarship on police officer masculinity, the strength with which Crowley clung to his request suggests he did so because his masculine self-esteem had been pricked. ${ }^{232}$

\section{b. Gates's Requests for Crowley's Name and Badge Number}

Gates also violated the rule of deference to the badge by repeatedly demanding Crowley's name and badge number. Crowley likely perceived this response to be an act of defiance. Officers appear quite sensitive to the suggestion they might be rebuked for abuse of discretion. Such sensitivity seems manifest in the "blue wall of silence" 233 as to officer misbehavior, and in police union resistance to civilian review boards. ${ }^{234}$ For present purposes, we can expect an officer in Crowley's position to have been sensitive to the suggestion that Gates would not only refuse his request, but also seek to punish him for it. Gates's perceived as much: "[W]hen I demanded—which I did-[Crowley's] name and badge number, I think he just got really angry." 235 Crowley appears to have perceived Gates as violating the unwritten rule of deference to the badge by requesting his badge number and to have punished Gates's violation with the arrest.

232 See e.g., Cooper, “Who's the Man?," supra note 13, at 693-96 (defining the hegemonic pattern of police officer masculinity); Harris, supra note 29, at 781-82 (linking police officer masculinity to police brutality); MesserschmidT, supra note 174, at 178 (considering how masculinity is structured into the way police officers perform their duties).

233 Gabriel J. Chin \& Scott C. Wells, The "Blue Wall of Silence" as Evidence of Bias and Motive to Lie: A New Approach to Police Perjury, 59 U. PitT. L. Rev. 233, 250-53 (1998) (discussing contributing factors to the "blue wall of silence"). See also Barbara E. Armacost, Organizational Culture and Police Misconduct, 72 Geo. Wash. L. Rev. 453, 468 (noting police code of silence); Alan M. Dershowitz, Visibility, Accountability and Discourse as Essential to Democracy: The Underlying Theme of Alan Dershowitz's Writing and Teaching, 71 Alb. L. Rev. 731, 779 (2008) (explaining blue wall of silence); Richard C. Worf, The Case for Rational Basis Review of General Suspicionless Searches and Seizures, 23 Touro L. Rev. 93, 178-79 (2007) (discussing blue wall of silence in equal protection context).

234 See Armacost, supra note, 226 at 538-40 (discussing police resistence to civilian review boards).

235 Elizabeth Gates, My Daddy, the Jailbird, The Daily Beast (July 22, 2009, 6:26 AM), http://www.thedailybeast.com/blogs-and-stories/2009-07-22/my-daddy-the-jailbird/. 


\section{c. Gates Calling Crowley a Racist}

Crowley also likely perceived Gates calling him a racist as a violation of the rule of deference to the badge. To see why this is so, one need only note that calling someone racist has become a grave incivility. ${ }^{236}$ Because the challenge has become downright rude, it violates the rule of deference. That argument will be more fully developed later in relation to post-racialism and "playing the race card."237

\section{d. Gates's Suggestion He Was a "Bigger Man” Than Crowley}

The final way in which Gates challenged Crowley's masculinity was by suggesting he was a "bigger man" than Crowley. As suggested earlier, men are often anxious about their masculine esteem and respond to that anxiety by competing to demonstrate their relative masculinity. ${ }^{238}$ Gates's relative importance was implicit in the prestigious and expensive location of his home. Ware Street is close to Harvard Square and located in one of Cambridge's better neighborhoods. The eventual revelation of Gates's status as a Harvard professor also made his relative stature implicit. ${ }^{239}$ Having grown up in Cambridge and graduated from its public high school, Crowley was surely aware of the prestige of Gates's neighborhood and affiliation. ${ }^{240}$

Gates made his implicit stature explicit by telling Crowley he did not know whom he was messing with. ${ }^{241}$ Specifically, Gates let Crowley overhear that he was calling a "chief." 242 While talking to that person, he referred to Crowley as a racist officer whom he was dealing with. ${ }^{243}$ Gates then made the first of his statements to Crowley that he did not know whom he was messing with and the first of his threats to Crowley that he had not heard the end of this. ${ }^{244}$ These statements implied that Gates was too big of a man to be challenged by Crowley, who was thus implicitly a lesser man. Gates was threatening Crowley, which helped transform this event into a masculinity contest.

\section{The Masculinity Contest Between Crowley and Gates}

As a result of Gates's challenges to Crowley's masculinity, and Crowley's simultaneous challenges to Gates's masculinity, the parties were in a masculinity contest at the time of the arrest in at least three ways. First, there was the issue of whether or not Gates would follow Crowley's request and leave his house. As noted, Gates's refusal of this request challenged Crowley's police

236 See Charles McIlwain, The Steady, Subversive Redefintion of 'Racism', NEwsDAY (N.Y.), July 17, 2009, at 35 (discussing "reverse racism").

237 See discussion infra Part IV.B. (arguing post-racialism makes claiming racism offensive).

238 See discussion supra Part III.A.

239 See Crowley, Incident Report, supra note 2 at 2 (reporting receipt of Gates's Harvard identification card).

240 See Jonathan Saltzman, Sergeant at Eye of Storm Says He Won't Apologize, Boston Globe, July 23, 2009, at 1 (reporting Crowley graduated from Cambridge Rindge \& Latin High School). The author is also a CRLS graduate.

241 Crowley, Incident Report, supra note 2, at 2 (describing two such claims).

242 See id. (describing overhearing conversation).

243 Id.

244 Id. 
authority, and thus his masculinity. ${ }^{245}$ Simultaneously, Crowley's insistence that Gates leave the house challenged Gates's masculinity. Would Gates stand his ground or back down?

A second way this became a masculinity contest was Crowley's claim that Gates said derogatory things about Crowley's mother. ${ }^{246}$ If we take this as true, it is the classic challenge to a fight. After all, a real man stands up for his mother. If Gates said something about Crowley's mother, he initiated a masculinity contest with Crowley. Certainly, an arrest would be an adequate response, at least in the sense of having staunchly defended one's manhood. However, Gates denies saying it, ${ }^{247}$ and there is reason to believe him. It seems particularly unlikely a black man would say this to a cop because black men are generally raised to believe that police officers are prone to beating black men. ${ }^{248}$

Regardless of whether the statement was made, the claim of such a statement is still indicative of a masculinity contest. If Crowley believed Gates said it, he would certainly have felt Gates challenged his masculinity. If Crowley knew Gates made no such statement, he might have believed he needed to concoct an insult in order to justify the arrest. Such a false claim would ratchet up the masculinity contest already in progress. Either way, both parties suffered insults they were likely to take as challenges to their manhood. The claim Gates said "your mama" 249 would be just another move in the game of claiming bad behavior.

A third way in which the Gates arrest became a masculinity contest was Gates's later request for, and Crowley's refusal to give, an apology. ${ }^{250}$ Crowley accused Gates of bad behavior with his arrest for disorderly conduct. Gates counter-claimed bad behavior by calling Crowley a racist. The request for an apology was a continuation of the masculinity contest. Now the question was whether or not Crowley would apologize to Gates. Would he stand his ground or back down? Of course, he stood his ground, and this masculinity contest became a national event. ${ }^{251}$

Legal scholar Paul Butler supports reading the Gates arrest as stemming from a violation of the rule of deference, creating masculinity challenges for Gates and Crowley, and resulting in a masculinity contest. He says the event became a "Who's the man?" contest. ${ }^{252}$ Because Gates kept yelling at Crow-

245 See Scott, supra note 190, at 12 (contending police officers link respect for their role authority and respect for their manhood); Martin, supra note 191, at 117 (same).

246 See Crowley, Incident Report, supra note 2, at 2 (alleging reference to Crowley's "mama").

247 See Judith Warner, Op-Ed., A Lot Said and Unsaid, About Race, N.Y. Times, July 26, 2009 , at A21 ("The idea that I would, in a vulnerable position talk about the man's mother is absurd").

248 See Devon Carbado, (E)racing the Fourth Amendment, 100 Мich. L. Rev. 946, 966-67, 1020 (2002) [hereinafter Carbado, (E)racing] (describing belief in risk of beating).

249 See Crowley, Incident Report, supra note 2, at 2.

250 See Laurel J. Sweet et al., Officer in Gates Flap Tried to Save Reggie Lewis, Boston Herald, July 23, 2009, at 5 (referring to apology request by saying that in doing so, Gates "went on the attack").

251 See id. (reporting Crowley's refusal to apologize).

252 Page, supra note 146 (paraphrasing Paul Butler); see generally Cooper, Who's the Man?, supra note 13 (coining the term). 
ley, especially in front of his fellow officers, he violated the rule of deference. $^{253}$ Accordingly, his arrest was really for "contempt of cop." 254 As journalist Clarence Page put it, "You disrespect the police officer, the officer has ways of showing you that he has the last word." 255 It is appropriate to see Gates's violations of the rule of deference as having presented Crowley with a masculinity challenge that Crowley ratcheted up to a masculinity contest and sought to resolve with the arrest.

\section{Implications of Reading the Arrest as Machismo}

Ultimately, we should understand Crowley's decision to arrest Gates as more than racial profiling. It should also be understood as a product of machismo. Although it is hard to imagine that a famous white Harvard professor (e.g., Alan Dershowitz) would have been arrested after the officer identified him and determined he did not commit a crime, ${ }^{256}$ it is also hard to imagine that a famous black female Harvard professor (e.g., Lani Guinier) would have been arrested under these circumstances. ${ }^{257}$ In order to fully understand the arrest, it is necessary to see it as a multidimensional product of Crowley and Gates's races, Gates's claim of racism, Crowley's sensitivity to that charge, the relative class positions of the parties, and the fact that they are both men.

\section{Post-racialism and the Response to the Arrest}

Although machismo has not been fully understood as a factor leading to Crowley's arrest of Gates, when it comes to the popular response to the arrest, post-racialism has also been underestimated as a factor. Some people responded by immediately doubting that Crowley's decision to arrest Gates was race-based. ${ }^{258}$ Many were critical of President Obama's statement that the Cambridge Police Department acted stupidly. ${ }^{259}$ That criticism seems to have been race-specific, with whites disapproving of the comments while blacks did not. ${ }^{260}$ One might even go so far as to say that criticism of Obama's handling of Crowley's arrest of Gates was a significant stimulus of his drop in popularity among whites from the end of the summer of 2009 to March $2010 .^{261}$

However, the most striking aspect of the criticism was the suggestion that Gates was the true racist in the situation. ${ }^{262}$ Given the apparent prior consensus

253 Page, supra note 146 (paraphrasing Paul Butler).

254 Id.

255 Id.

256 See Goodnough, supra note 8, at A13 (quoting contention white professor would not have been arrested).

257 See Vennochi, supra note 24, at 17 (arguing the arrest was the product of machismo). 258 See Doherty, supra note 23, at B-3 (noting argument arrest was race-based).

259 See Williams, supra note 107, at A15 (noting criticism of Obama statement).

260 See Elliott, supra note 116, at 3.

261 See Kingley Guy, Op-Ed., Don't Blame Racism for Obama's Ratings, Sun Sentinel (Fort Lauderdale), Mar. 12, 2010, at 21A (noting Obama's continuing unpopularity). Other reasons include the backlash against health reform and the dismal state of the economy.

262 See Lachlan Cartwright \& Jennifer Fermino, Gates Flap Nails Beep Aide-Ousted Over Web Jabs at Prof \& 'O-Dumb-A', N.Y. Post, July 29, 2009, at 7 (relating criticism of Gates as racist for claiming Crowley racial profiled him). 
that racial profiling is wrong, ${ }^{263}$ criticism of Gates for claiming racial profiling may suggest a change in popular thinking about race. The criticism of Gates as the true racist was largely the product of post-racialism, a frame of mind the U.S. mainstream only recently adopted. The main tenet of post-racialism is that the United States is now in a "post-racial" era-a period when the public has moved beyond race. ${ }^{264}$

To set the stage for discussing how post-racial ideology influenced the response to Crowley's arrest of Gates, this Part begins with a brief summary of the critical race theory of law. It then argues that post-racialism has its roots in the right-wing version of colorblindness, and that it leads to denigration of any claim of racism as "playing the race card." Finally, this Part demonstrates how post-racialism made it easier for people to see Gates as the true racist than to see Crowley as implicitly biased.

\section{A. Critical Race Theory Methodology}

Like masculinities studies, critical race theory is an interdisciplinary field. ${ }^{265}$ A fundamental premise of critical race theory is that race is not a natural phenomenon, but a social construct. ${ }^{266}$ Society constructs frameworks for what is expected of particular identity groups, and individuals perform their identities in accordance with or in opposition to those frameworks. ${ }^{267}$ However, to say that race is socially constructed is not to say that it is materially inconsequential. ${ }^{268}$ Rather, the profiles of races help identify social expectations that individuals will have to deal with. For instance, Crowley might have no implicit bias against blacks, but, as was noted above, Gates may have interpreted Crowley's actions in light of his knowledge that some police officers have associated blacks with crime. ${ }^{269}$ "Race matters" because of how it is interpreted, not because of any biological determinism. ${ }^{270}$

A second premise of critical race theory is that identities are hierarchized. Western epistemology has long entertained a "scaling of bodies" whereby whiteness is ranked over blackness, maleness is ranked over femaleness, heterosexuality is ranked over homosexuality, and so on. ${ }^{271}$ For present purposes,

263 See Johnson, supra note 25, at 1006 (noting surprising nature of Supreme Court's acceptance of racial profiling).

264 See generally Cho, supra note 29, at 1597-98 (describing distinction between colorblindness and post-racialism).

265 See, e.g., Cooper, Our First Unisex President?, supra note 155, at 643 (defining critical race theory).

266 See id. at 641-42 (defining shared tenets of critical race theory and masculinities studies).

267 See id. at 638-41 (defining performativity theory).

268 See, e.g., id. at 643 (describing identities as simultaneously constructed and materially consequential).

269 See supra text accompanying notes 215-24 (arguing that, as a black man, Gates may have felt his masculinity especially challenged by Crowley's suggestion that he was a criminal).

270 See generally Cornel West, Race Matters (Beacon Press 2001) (1993) (declaring continuing salience of race).

271 See Cooper, Against Bipolar Black Masculinity, supra note 25, at 870-73 (utilizing concept of the scaling of bodies); Iris Marion Young, Justice And the Politics of DifferENCE 126-28 (1990) (describing system of scaling of bodies). 
the most important vestige of the scaling of bodies is ongoing implicit bias. This bias against historically subordinated groups has been demonstrated to exist at a subconscious level despite individuals' explicit reports that they are free of bias. ${ }^{272}$ Implicit biases prevail because identities have been hierarchized.

One of the principal concerns of critical race theory is the critique of "colorblindness." 273 Colorblindness says noticing color by acknowledging someone's racial difference, for instance, is racist. ${ }^{274}$ The call for colorblindness originated as a radical challenge to the United States' "Jim Crow" system of de jure segregation. ${ }^{275}$ Consequently, Justice John Marshall Harlan's call for a colorblind constitution was drowned out by a seven-justice majority in Plessy $v$. Ferguson. ${ }^{276}$ Likewise, Martin Luther King Jr.'s call for colorblindness was seen as a thoroughgoing critique of the status quo, so much so that the FBI sought to undermine his ability to lead the black civil rights movement in the 1960 s. $^{277}$

In keeping with critical race theory's social construction premise, this Article views colorblindness as an empty sign whose meaning is subject to manipulation. ${ }^{278}$ Numerous scholars have noted that colorblindness tacitly maintains the primacy of whiteness. ${ }^{279}$ This Article adds to the scholarship on colorblindness by tracing both how colorblindness has its roots in the post-civil rights backlash that began at the end of the 1960s and how post-racialism springs from colorblindness.

\section{B. Post-racialism and "Race Cards"}

In her recent article Post-Racialism, Sumi Cho argues that post-racialism is, at heart, race-neutral universalism. ${ }^{280}$ The idea is that everyone shares a

272 See generally Kang, supra note 19 (explicating implicit bias's implications for law).

273 See, e.g., Cooper, Our First Unisex President?, supra note 155, at 644 (listing tenets of critical race theory).

274 See, e.g., Cooper, Against Bipolar Black Masculinity, supra note 25, at 884 (arguing colorblindness is an implicit requirement for black men to advance in corporate environments).

275 On the term "Jim Crow," see, for example, Kate Tuttle, Jim Crow, in Africana: The Encyclopedia of the African and African American Experience 1050-51 (Kwame Anthony Appiah \& Henry Louis Gates, Jr. eds., 1999) (discussing term).

276 See Plessy v. Ferguson, 163 U.S. 537, 559 (1896) (Harlan, J., dissenting) (declaring, "Our Constitution is color-blind").

277 See generally Frank Rudy Cooper, Surveillance and Identity Performance: Some Thoughts Inspired by Martin Luther King, 32 N.Y.U. Rev. L. \& Soc. Change 517 (2008) (applying identity performance theory to surveillance law in light of FBI harassment of King).

278 See Haney López, supra note 29, at 1062 (noting colorblindness uses civil rights rhetoric to forestall civil rights remedies).

279 See, e.g., powell, supra note 28, at 789-98 (detailing ways supposedly universal programs actually privileged white males).

280 See Cho, supra note 29, at 1592 (arguing that critical race theorists must acknowledge post-racialism's success in forging a mainstream consensus about what constitutes race neutrality). 
universal humanity, and we are beyond using race to distinguish ourselves. ${ }^{281}$ In that sense, it uses the colorblind ideology.

It is helpful to compare and contrast post-racialism and colorblindness. Whereas colorblindness is largely aspirational (i.e., acting as if there is no color will help us get to racial equality), ${ }^{282}$ post-racialism declares an end to this country's history of racism. Given President Obama's election, some contend the fight for racial equality has already been won. ${ }^{283}$ Cho defines post-racialism based on the following tenets: it congratulates the public for the progress it has made on race, ${ }^{284}$ it decries race-based remedies as partial rather than universal, ${ }^{285}$ it draws a moral equivalence between use of race to subordinate racial minorities and use of race to remedy such subordination, ${ }^{286}$ and it distances itself from prior race-conscious civil rights advocates. ${ }^{287}$

\section{Colorblindness as a Source of Post-racialism}

As part of a racial project designed to roll back civil rights reform, conservatives have succeeded in making post-racialism mean every explicit use of race is morally wrong. ${ }^{288}$ According to Cho, post-racialism is a racial project because it "organizes the distribution of resources by the state according to racial categories." 289 Cho sees such a project beginning in the post-1954 conservative movement's "promotion of a larger national and legal consensus that ignores the bulk of racial disparities . . . and pursues race-neutral remedies as a fundamental, a priori value." 290 Cho refers to the conservative movement as the "Racial Backlash" movement because its impetus and continuing force draw from resentment of progress by racial minorities. ${ }^{291}$ To support this claim, it is helpful to link post-racialism's predecessor, colorblindness, to conservative political ideology.

The present use of colorblindness as a critique of race-based remedies stems from the post-civil rights racial backlash that began in the 1960s. As legal scholar Allen Hunter put it, "The broad political anger at blacks was a central part of the [creation of Middle America] and centered on such issues as crime, law and order, and expansions of the welfare state."292 According to Hunter, both political conservatives, who actively opposed black civil rights,

281 See Haney López, supra note 29, at 1061 (defining colorblindness).

282 See Cho, supra note 29, at 1598 (distinguishing colorblindness as aspirational).

283 Id. at 1595 ("Centuries of racial apartheid and neo-apartheid are eclipsed by a symbolic 'big event' signifying transcendent racial progress.").

284 See id. at 1601 (defining racial progress strand of post-racialism).

285 Id. at 1602.

286 Id. at 1603.

287 Id. at 1603-04.

288 See Haney López, supra note 29, at 1061. Colorblindness as currently constructed was a direct response to the 1960's Civil rights movement. See id. at 1061-62 (dating colorblindness to 1970s).

289 Cho, supra note 29, at 1594.

290 Id. at 1592.

291 Id. (calling on Critical Race Theorists to deconstruct and challenge post-racialism).

292 Allen Hunter, The Role of Liberal Political Culture in the Construction of Middle America, 42 U. Miami L. Rev. 93, 119 (1987). 
and white liberals, who supported black civil rights to a limited degree, ${ }^{293}$ helped create the environment for the racial backlash. ${ }^{294}$ Conservative and liberal elites ended up shifting most of the costs of black progress onto the white middle and working classes. ${ }^{295}$ Hunter thus concludes that "[b]y maintaining basically racist social and economic structures-and barely addressing the class dimensions of racial oppression-much of the material and symbolic cost of the slight diminution of racism was borne by working class and middle strata whites, not the rich." 296 Shifting the costs of black civil rights to the white working and middle classes fueled animosity, and thus the maintenance of widespread implicit bias against blacks even as explicit bias receded.

That is where the Republican Party's "Southern Strategy" came in. The Southern Strategy is a racial project. As Mark Thompson explains, "The 'Southern Strategy' is a phrase used to describe the focus of the Republican Party on winning U.S. presidential elections by securing votes from the Southern states, initially through the promotion of states' rights." 297 The Republican Party was able to expand its Southern base by adding midwestern cultural conservatism to its states'-rights base. ${ }^{298}$

Present day states' rights, cultural values, and fiscal responsibility arguments continue to promote racism. As Lee Atwater admitted in 1981:

You start out in 1954 by saying, "Nigger, nigger, nigger." By 1968 you can't say "nigger"- that hurts you. Backfires. So you say stuff like forced busing, states' rights and all that stuff. You're getting so abstract now [that] you're talking about cutting taxes, and all these things you're talking about are totally economic things and a byproduct of them is [that] blacks get hurt worse than whites. And subconsciously maybe that is part of it. . . . You follow me-because obviously sitting around saying, 'We want to cut this,' is much more abstract than even the busing thing, and a hell of a lot more abstract than "Nigger, nigger."299

In this sense, contemporary conservative ideology is in privity with explicitly racist arguments. The way colorblindness continues that tradition is by means

293 Id. at 120 (saying of liberals, "they rhetorically promoted racial change beyond the point to which they were actually willing to materially or ideologically commit themselves").

${ }^{294}$ Hunter argues as follows:

From the mid-1950's, economic forces, modest elite political actions, and especially black civil rights movements, were woven into a challenge to those features of the established social structure of accumulation that sustained de jure segregation. Nonetheless, in the context of my argument that Middle America was not only discovered, but invented, elite political and economic groups, along with conservative politicians, contributed to Middle American hostility to civil rights.

Id. at $119-20$.

295 Id.

296 Id. at 120-21. Hunter continues as follows:

When living standards were leveling off and taxes were increasing, white people who did not question the nation-state or class structures could see poor blacks as joined with liberal elites in an attack on society's producers. This emphasis on a productive/unproductive split is a recurrent image that conservatives recently have used to promote racial, not class divisions. Id.

297 Mark R. Thompson, When God Collides with Race and Class: Working-class America's Shift to Conservatism, 68 U. PITt. L. Rev. 243, 251 (2006).

298 Id.

299 Id. at 254. 
of a similar implicit understanding that it is a policy whereby blacks "get hurt worse than whites." 300

In a recent article, Post-Racial Racism: Policing Race in the Age of Obama, legal scholar Ian Haney López states colorblindness does "much of the intellectual and emotional work of justifying" the racial status quo. ${ }^{301}$ For Haney López, the racial status quo is characterized by "racial stratification," which means wealth, power, and prestige are allocated in a pattern best explained by race. ${ }^{302}$ Racial stratification in the U.S. is evidenced by the disproportionate number of whites occupying the top of society, and the disproportionate number of racial minorities occupying the bottom. ${ }^{303}$

Colorblindness helps justify racial stratification in at least two significant ways. First, colorblindness justifies racial stratification by defining any action not intentionally based on an invidious use of race as presumptively "notracism." 304 This use of colorblindness operates by requiring the actor's intent be demonstrated to establish an Equal Protection claim. Legal scholar Devon Carbado describes this problem in the context of Fourth Amendment jurisprudence:

$[R]$ ace becomes doctrinally relevant only to the extent that the presumption of race neutrality and colorblindness can be rebutted by specific evidence that a particular police officer exhibits overtly racist behavior ... only when a case involves a "racially bad" cop. Police officers who cannot be so described are presumed to be "racially good."305

Consequently, absent a showing of a racial epithet or other expression of racially invidious intent, courts assume racial discrimination does not exist. ${ }^{306}$ This is so even where the practice is closely correlated with racial hierarchy. ${ }^{307}$

In the law enforcement context, colorblindness as not-racism shields stark racial disparities from scrutiny. ${ }^{308}$ This is so even when parties demonstrate disparities so wide that they are extremely hard to explain as anything other than a product of race and when they demonstrate that a policy was expressly race conscious, albeit motivated in part by a non-invidious goal. The racial disparity apparent in the assignment of the death penalty and the racially disparate distribution of police stops based on racial profiling each survive scrutiny. ${ }^{309}$ In each case, one cannot prove the policy was solely both intentionally

300 Id. (quoting Lee Atwater); see also Carbado, (E)Racing, supra note 248, at 975 ("[C]olorblindness is not in fact race neutral, but instead reflects a particular racial preference that systematically burdens nonwhites.").

301 Haney López, supra note 29, at 1061. Haney López attributes colorblindness's success as an ideology to the fact that it has become "commonsense," which he defines as "an accepted, taken-for-granted ideational matrix that operates at a non-conscious level as a baseline for judging what is normal, moral, and legitimate in the world." Id.

302 Id. at 1027.

303 On race-class stratification, see $i d$. at 1050 (saying race and class operate "[s]eparately and together").

304 See id. at 1062 (defining "not-racism" approach).

305 Carbado, (E)racing, supra note 248, at 968-69.

306 Haney López, supra note 29, at 1062.

307 Id.

308 Id.

309 See McClesky v. Kemp, 481 U.S. 279, 319 (1987) (holding stark disparities in imposition of death penalty based on races of victim and perpetrator do not violate Equal Protection 
and invidiously race based, so colorblindness requires one to presume the policies are not-racism.

A corollary of the not-racism rule, and a second way in which colorblindness justifies racial stratification is that coded appeals to racial stereotypes about the cultures of racial groups are deemed not racist. When conservative proponents justify draconian polices by suggesting that certain groups produce "super predators" or "terrorists," it not only removes the need of the proponent to say they want race-based policies because of a dislike for the subject's race, but it also shields the policies from claims of racism. ${ }^{310}$ David Garland has pointed out that the public knows such terms refer to specific racial minority groups. ${ }^{311}$ Given that knowledge, acceptance of cultural attacks is more than a failure to see racism; it is a refusal to do so. ${ }^{312}$ Stoking fear of crime can be seen as non-racist even though it was created for the very purpose of serving as a coded appeal to racist voters. ${ }^{313}$

Such coded appeals work precisely because of the way colorblindness justifies racial stratification. According to Haney López, racial inequality is common sense for many in the United States. ${ }^{314}$ Whereas the belief that racial minorities are crime prone actually stems from the cumulative effect of centuries of linking crime control to race, it is thought to stem from reason. ${ }^{315}$ Haney López explains why: "Partly through colorblindness and partly through the accumulated weight of cultural beliefs and historical practices, most Americans accept that major American institutions are race neutral and that these institutions produce vast racial disparities." 316 Consequently, "For many Americans, racial disparities in the criminal justice system not only fail to evoke a sense of moral outrage, but engender instead a belief in the basic fairness of the world as currently organized." 317

The logic is simple: there is no more (explicit) racism, so any remaining racial disparities must be natural. Colorblindness buttresses that view. By defining the current racial climate as not racist, it leaves the rational pursuit of crime as the most comprehensible explanation for racially disparate policing. There is certainly an incentive to reach that conclusion. For instance, one might worry that hyper-incarceration reflects poorly on society as a whole. Yet, as legal scholar Kenneth Nunn notes, if our massive criminal justice appa-

doctrine); Whren v. United States, 517 U.S. 806, 813 (1996) (responding to argument officers alleged racial profiling invalidated a seizure by saying, "We think these cases foreclose any argument that the constitutional reasonableness of traffic stops depends on the actual motivations of the individual officers involved."); see also Haney López, supra note 29, at 1062 (describing not-racism effect).

310 See Haney López, supra note 29, at 1063-64 (discussing examples of cultural attacks).

311 See generally David Garland, The Culture of Control: Crime and Social Order in Contemporary Society 183 (2002) (arguing people understand code words apply to young black males).

312 See Haney López, supra note 29, at 1063-64 (labeling the phenomenon "refusing to see race in cultural attacks").

313 Id. at 1063 , n. 179.

314 See id. at 1064 (explicating the "seeming naturalness" of racial inequality).

315 See id. (contending acceptance of racial stratification is "traceable to the days of white supremacy").

316 Id. at 1066 (emphasis in original).

317 Id. at 1064. 
ratus can be explained by the need to contain racial others, then it is not a bad reflection on society as a whole. ${ }^{318}$

\section{Post-racialism and "Playing the Race Card"}

Like colorblindness, "post-racialism [is] an ideology [that] . . . reinstate[s] an unchallenged white normativity." 319 What is deemed universal is that which comports with the norms of upper middle-class white culture. ${ }^{320}$ Both colorblindness and post-racialism assume that significant racial progress has been made to the point that we need not engage in race-based debate, remedies, or decision making. ${ }^{321}$ Both ideologies seek to simultaneously illegitimatize both explicit (but not implicit) racism and racial minorities' "racial obsession" with the racist past. ${ }^{322}$

According to Cho, although post-racialism shares some common traits with colorblindness, it actually goes beyond the work of the colorblindness ideology. ${ }^{323}$ The main difference, Cho argues, is that colorblindness was aspirational in its demand for a "retreat from race." ${ }^{324}$ Post-racialism assumes we have actually attained significant racial progress. ${ }^{325}$

A consequence of post-racialism is the eschewing of anything resembling "playing the race card." "Playing the race card" is thought to occur when one blames a result on race. ${ }^{326}$ It can be understood as a refusal to remain colorblind because it brings race to the forefront. To post-racialists such as Richard Thompson Ford, author of the book The Race Card: How Bluffing About Bias Makes Race Relations Worse ${ }^{327}$ the only creditable claims of racism are those that can show intentional prejudice as the motivator. ${ }^{328}$ These cases include "legally traceable causation" involving an "underprivileged victim pursuing relief from material disadvantage, political disenfranchisement, or violent repression." 329 In other words, the discrimination must be both explicit and verifiable in order to warrant claiming racism has occurred. ${ }^{330}$ Ford does acknowledge the existence of institutional racism, but he views it as "diffuse,

318 See Kenneth B. Nunn, Race, Crime and the Pool of Surplus Criminality: Or Why the “War on Drugs" Was a "War on Blacks", 6 IowA J. Gender RACE \& Just. 381, 385 (2002) (arguing the drug war demonstrates that blacks occupy a pool of surplus criminality and are drawn upon as boogey-men when a need for demonization arises).

319 Cho, supra note 29, at 1593.

320 See generally Barbara J. Flagg, Was Blind, But Now I See: White Race ConSCIOUSNESS AND THE LAW (1998) (arguing colorblindness supports white privilege).

321 Cho, supra note 29, at 1594.

322 Id. at 1604.

323 Id. at 1597.

324 Id. at 1598.

325 Id. at $1594-95$

326 See id. at 1634 (listing five ways Richard Thompson Ford sees people as "playing the race card").

327 Richard Thompson Ford, The Race-Card: How Bluffing About Bias Makes Race Relations Worse 20 (2008) [hereinafter The Race CARD] (arguing that playing the "race card" in racially ambiguous circumstances abuses and manipulates racial sympathies).

328 Cho, supra note 29, at 1634-35.

329 Id.

$330 I d$. 
ambiguous, and implicit" in nature. ${ }^{331}$ Cho explains that Ford's work fits within post-racialism because under his theory, there are "virtually no racists" and "outright bigot[ry] has been transcended." 332

In Christopher Bracey's book review of Ford's The Race Card, he denounces Ford's proposition that "playing the race card 'places all claims of racism . . . under a cloud of suspicion." "333 Bracey contends that promoting suspicion of racism claims, despite the continuing vitality of explicit ${ }^{334}$ and implicit ${ }^{335}$ racial bias, creates a post-racial culture wherein there is "racial injury without racists." 336 He believes Ford's approach of adopting a "cooperative spirit of dialogue" when speaking about perceived injustices merely substantiates the popular belief that if we simply implement a "cooler tone," then race relations will improve. ${ }^{337}$ In Bracey's view, the claim that one is promoting post-racialism provides an excuse for accusations that racial minorities are "playing the race card." 338 He finds unsettling the idea of "telling someone else how they should respond to a perceived injustice, or that their perception of reality is at best inappropriate and at worst somehow invalid." 339

For Bracey, the real problem with "playing the race card" is that U.S. culture has no common conceptualization of what racism is. ${ }^{340}$ "Playing the race card" by alleging discrimination could only work in a society with a collective understanding that racism is ongoing and morally wrong. ${ }^{341}$ Postracialism creates the opposite effect by eliminating race from the discussion

331 Id. at 1636 (quoting Ford, The RACE CARD, supra note 320, at 91) (internal quotation marks omitted).

332 Id. at 1635.

333 Bracey, supra note 29, at 91.

334 See, e.g., Rhonda V. Magee, Competing Narratives, Competing Jurisprudences: Are Law Schools Racist? and the Case for an Integral Critical Approach to Thinking, Talking, Writing, and Teaching About Race, 43 U.S.F. L. Rev. 777, 780-81 (2009) (arguing racism against black law students is clear).

335 See, e.g., Susan A. Bandes, Emotions, Values, and the Construction of Risk, 156 U. PA. L. REv. 421, 432 (2008) (response) (arguing we cannot avoid evaluating data using implicit biases).

336 Bracey, supra note 29, at 102 (quoting Ford, THE RACE CARD, supra note 320, at 92) (internal quotation marks omitted).

337 Id. at 92-93 (quoting Ford, THE RACE CARD, supra note 320, at 349) (internal quotation marks omitted).

338 Id. at 97-98. Bracey states as follows:

I cannot help but think of centuries of devastating modes of oppression levied upon Blacks and other racial minorities at the hands of Whites. Indeed, if we agree that the purpose of the card is to harness the power of race rhetoric and the legacy of racism in order to secure some ill-gotten advantage or windfall, I can think of no greater windfall in American history than that of White skin privilege-the set of benefits and accoutrements of unearned (and largely unquestioned) status born from the ritual playing of the race card by bigoted Whites.

Id. Later, he elaborates on the premise that whites are the principal players of "race cards": The classic form of playing the race card is the principal means through which Whites (past and present) have capitalized on racial fears, anxieties, and assumptions about the status of racial minorities in American life. And it remains the surest means to maintain the longevity of these retrograde ideas against the swelling tide of racial progress.

Id. at 98 .

339 Id. at 107.

340 Id. at 100 .

341 Id. 
altogether. Consequently, says Bracey, "[W]e seem to lack agreement of the kinds of incidents worthy of our sympathy." ${ }^{342}$ Post-racialism ends up devaluing evidence of racial disparities because not discussing racial injustice means racial disparities become naturalized. ${ }^{343}$ In such a climate, many presume that racism has disappeared. ${ }^{344}$

In another review of Ford's The Race Card, Julie Suk analyzes Ford's contention that race relations suffer when people play the race card. ${ }^{345}$ She agrees with Ford that "playing the race card" is a powerful, yet sometimes counterproductive approach, but for different reasons than Ford. ${ }^{346}$ Racism has become such a grave incivility and is presumed so rare, that accusing someone of racism can be a significant political move. ${ }^{347}$ It produces shame, and therefore "the alleged racist may feel compelled to do whatever it takes to shake off such an odious label." ${ }^{348}$ Instead, however, those accused of racism might become so outraged at the "false" accusation that they stop taking any claims of racial bias seriously. ${ }^{349}$ As a result, legitimate claims of racism are discounted and ignored. ${ }^{350}$

Suk notes that sometimes "the mere identification of racial injustice is sometimes misunderstood as an accusation of racism." 351 Because post-racialism is only successful when race is not acknowledged, when one legitimately identifies racial discrimination, the opposition desires a means of retaliation. Persons who perceive themselves accused of racism may in turn accuse their interlocutors of "playing the race card." 352 They play the "retaliatory "race card' card." 353 "The "race card' card is played to avoid engaging the merits of a claim of racial prejudice or injustice. ${ }^{354}$

So, Ford is technically correct that instead of initiating an honest debate or discussion about racial remedies, an accusation of racism tends to stifle discussion. ${ }^{355}$ But the acknowledgment of race (by "playing the race card") is not the culprit of alienation and antagonism. ${ }^{356}$ The real problem is that, in the postracial era, anyone accused of racism feels entitled to play the "'race card' card" before investigating the merits of a claim. Suk therefore joins Cho and Bracey in criticizing Ford's virtual blanket proscription on pointing out racial disparities.

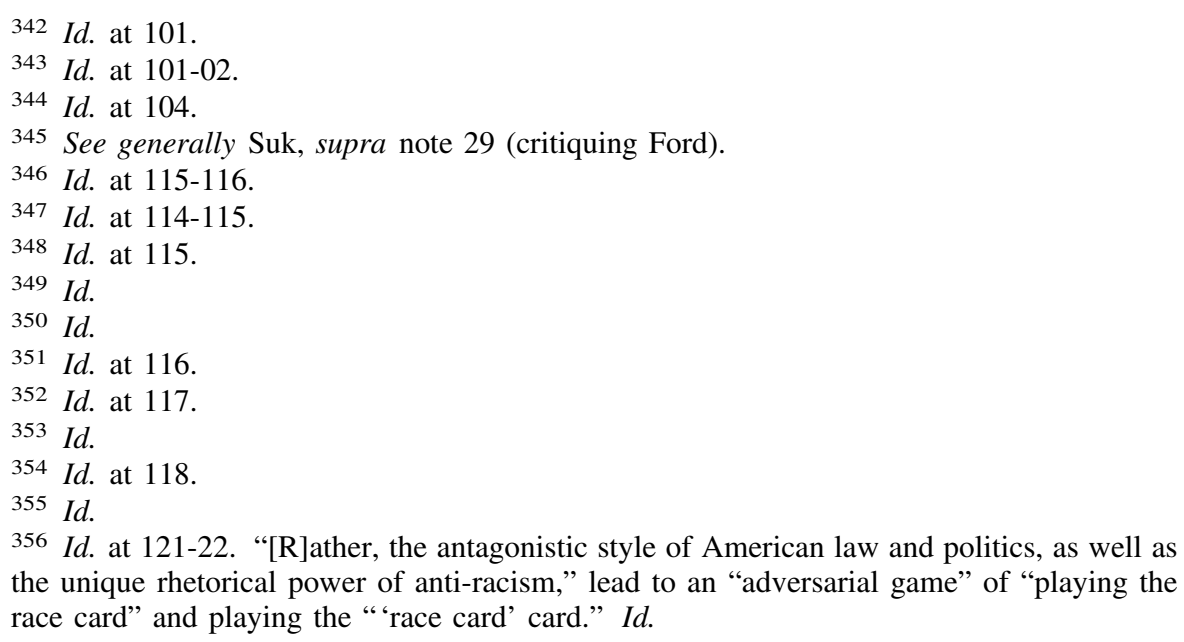


Under post-racialism, anyone who refuses to remain colorblind-by suggesting victimization because of race-is presumptively subject to suspicion. ${ }^{357}$ The mainstream of racial majorities tends to see claiming racism as a "dirty trick" that racial minorities use opportunistically. ${ }^{358}$ However, given ongoing racial stratification, implicit anti-racial minority bias, and explicit bias, post-racialists imagine a world of "racial injury without racists."359 As Haney López's analysis of responses to hyper-incarceration suggests, it is a situation where racial disparities can only be blamed on the victims.

\section{Post-racialism and Gates as the True Racist}

The Gates controversy is a perfect setting for a critical race theory analysis of post-racialism. One can see how race is socially constructed yet materially consequential when we consider Whalen's 911 call. Whalen told the dispatcher she could not determine the race of the suspects. ${ }^{360}$ Then she told the dispatcher one of the men might have been Hispanic. ${ }^{361}$ Whalen's confusion over the men's race is related to the fact that race is a social construction whereby individuals interpret the meaning of characteristics such as skin color and hair texture, sometimes incorrectly. ${ }^{362}$

Imagine the difference it would have made had Whalen said the two men were black or white instead of Hispanic. Stereotypes about black criminality mean that invoking the possibility of a black man's involvement in a break-in provides social cause (over and above legal cause) for scrutiny. ${ }^{363}$ The ready understandability of the imperative for a cop to investigate two black men forcing a door in a rich white neighborhood might explain why Crowley (mis)understood Whalen to have said the suspects were black. ${ }^{364}$ If Whalen

357 Bracey, supra note 29, at 91 (quoting FORD, THE RACE CARD, supra note 320, at 19, for the proposition that the existence of some false claims of racism "places all claims of racism ... . under a cloud of suspicion") (internal quotation marks omitted).

358 Id. at 94.

$359 \mathrm{Id}$. at 102.

360 See Bello, supra note 56, at A3 (describing Whalen's call).

361 See id. (relating Whalen's words).

362 On the social construction of race, see, for example, Angela Onwuachi-Willig \& Mario L. Barnes, By Any Other Name?: On Being "Regarded as" Black, and Why Title VII Should Apply Even if Lakisha and Jamal Are White, 2005 WIs. L. REv. 1283, 1296 (arguing racial discrimination is often based upon social constructed ideas about characteristics).

363 On the association between blackness and criminality, see, for example, Nunn, supra note 318 , at 385 (arguing blacks are inherently criminal in mainstream white imagination). 364 Compare Crowley, Incident Report, supra note 2, at 2 (claiming Whalen identified suspects as black) with Bello, supra note 56, at A3 (reporting that Whalen said she never identified the suspects as black).

Stereotypes about Latina/o criminality, while pervasive, especially in the context of immigration discourse, are not as powerful in most contexts as the association of blacks with criminality. This makes sense given the difference between a nearly 350 year history of slavery and Jim Crow and a history of U.S. imperialism in Latin America that was active for approximately 150 years. See generally Juan F. Perea et al., Race and Races: Cases and Resources for a Diverse America (2d ed. 2007) (collecting historical materials on treatment of races). On some ways in which anti-black and anti-Latina/o prejudice compare and contrast, see Ramón Grosfoguel \& Chloe Georas, "Coloniality of Power" and Racial Dynamics: Notes Toward a Reinterpretation of Latino Caribbeans in New York City, in Colonial Subjects: Puerto Ricans in a Global Perspective (2003) (arguing New 
had instead said the men were white, Crowley might have been subconsciously primed to approach the incident as more likely to be a case of a resident who had locked himself out of his home. ${ }^{365}$

In a situation where Crowley did not approach Gates with a best-case scenario in mind, post-racialism makes it hard to read Crowley as implicitly biased. Indeed, it makes it easier to read Gates as the true racist. This is so for three reasons: (1) Haney López's not-racism principle suggests that the lack of proof of Crowley's intent to racially profile requires a presumption that no racial bias was present; (2) Haney López's principle of the post-racial acceptance of coded appeals to racial bias seems present in a discourse labeling Gates as "arrogant"; and (3) in light of the analyses of Cho, Bracey, and Suk, we see Gates's opponents as having played the race-card card to suggest Gates was the true racist in the situation.

First, in the post-racialist's view, because Crowley did not express any explicit racism, his acts should be presumptively categorized as not racist. ${ }^{366}$ This is so even though Crowley says, apparently falsely, that he questioned Gates, in part, because Whalen told him "two black guys" had forced the door open. ${ }^{367}$ This is a color-conscious basis for action that is exempted from colorblindness's usual prohibition on noticing race because it has a facially noninvidious explanation - the need to investigate a suspect. ${ }^{368}$

Second, recall as well Haney López's demonstration that colorblindness does not see racism in coded appeals to racists. ${ }^{369}$ The post-racialists do not wish to see race as an explanation for actions, so they sometimes refuse to do so, even in the face of evidence to the contrary. ${ }^{370}$ In this case, a white officer seems to have made up a suspect description and then arrested a prominent intellectual after confirming there was no crime. Why would we not suspect implicit bias? The answer seems to be that many accepted a discourse about Gates's arrogance as the explanation for the arrest, a discourse with ties to an older racist narrative about black "uppityness."

The theme of Gates as arrogant runs through many accounts of the incident. For instance, a New York Post article quoted former political aide Lee Landor as blaming the incident on Gates's arrogance and his own racism. ${ }^{371}$ In

York-area Latina/o Caribbeans were either made black or whitened based on the colonial status of their native country).

365 See generally Thompson, supra note 19, at 956 (describing how stereotyping affects police officers' tendencies to investigate).

366 See Sweet et al., supra note 250 (implying Crowley is not racist because he tried to perform mouth-to-mouth resuscitation on a famous basketball player); Haney López, supra note 29, at 1062 (arguing colorblindness makes non-explicit bias not-racism); discussion supra Part III.B and accompanying text (explicating colorblindness's not-racism principle). 367 Crowley, Incident Report, supra note 2, at 2.

368 See Haney López, supra note 29, at 1062 (discussing "not-racism" principle). Colorblindness presupposes the fair operation of social institutions, and thus that there is good reason the police are more suspicious of blacks. See id. at 1066 (noting mainstream white belief in fairness of social institutions).

369 See discussion supra notes 310-13 and accompanying text (decrying ignoring of coded appeals).

370 See Haney López, supra note 29, at 1063-64 (arguing people refuse to see race in cultural attacks).

371 Cartwright \& Fermino, supra note 262, at 7. 
this view, the arrest was not the result of racial profiling, but of Gates's failure to cooperate: "If Mr. Big Shot Harvard would have kept his mouth shut, shown his ID and not started yelling at a police officer, he never would have been arrested. So please, it's times to get over this 'It's because I'm black' bull-_ ."372 Further, in a representative conservative editorial, Michael Graham accuses Gates of arrogance and links his attitude to reverse-racism. ${ }^{373}$ Finally, numerous letters to editors around the country blamed the incident on Gates being arrogant instead of humbly accepting the officer's right to investigate. ${ }^{374}$

We might read the arrogance/uppityness discourse as an example of Haney López's principle that colorblindness and post-racialism lead to the acceptance of coded appeals. While Gates might or might not be arrogant in general, that was not the shape the argument took. Rather, Gates's critics considered it arrogant to challenge a police officer who had come to his home to accuse him of burglarizing it after he had just returned from an international trip and continued to question him after he provided identification. Gates's reaction was understandable, if not even the natural one. So, something else is going on when critics call Gates arrogant.

One might argue that Gates is being criticized for being an "uppity Negro." No disrespect is meant by this term; this is how blacks have sometimes been characterized when they rise above their expected stations. For example, Devon Carbado notes that one narrative in the O. J. Simpson case was that Simpson had been an "uppity Negro." 375 In that view, Simpson's economic and popular-cultural success made some whites especially happy to see him knocked down. ${ }^{376}$ In Gates's case, he has often subtly been described as uppity in a way that suggests his claim of racial profiling is being turned into a sword against him. It may be that people were being invited to view the position of entitlement Gates held as illegitimate; perhaps on a presumption that it reflected affirmative action. Alternatively, people were invited to think any black in his position should be grateful and not claim racism. In either case, Gates was plugged into a traditionally racist narrative. As Haney López's theory of coded appeals would predict, there is no evidence the mainstream challenged the legitimacy of the association of Gates with uppityness.

Finally, in a post-racial world, it should be no surprise Gates was accused of "playing the race card." Relying on post-racial logic, people called Gates the true racist in ways that suggested post-racialism was at work. The abovementioned New York Post article quotes Landor as describing Gates as the true racist for "playing the race card." 377 In Landor's account, the arrest was not

372 Id. (quoting Lee Landor).

373 Michael Graham, Op-Ed., Colorblind Test Failed; It's Gates Who Plays Race Card, Boston Herald, July 23, 2009, at 19.

374 See, e.g., Bruce Clay, Letter to the Editor, Firestorm Over Gates Case, Boston Globe, July 27, 2009, at A12 ("Perhaps Gates's indignation was not so righteous this time.").

375 Devon W. Carbado, The Construction of O.J. Simpson as a Racial Victim, 32 HARv. C.R.-C.L. L. Rev. 49, 85-86 (1997) (noting uppity Negro narrative about Simpson).

376 Id. at 86; see also Terry McMillan, Op-Ed., An Icon, But Not a Hero, N.Y. Times, June 25,1994 , at 23 ("Plenty of folks, white and black, are secretly enjoying the spectacle of a successful black man's fall.").

377 Cartwright \& Fermino, supra note 262, at 7. 
the result of racial profiling, but of Gates's failure to cooperate. ${ }^{378}$ Landor seems to think Gates is covering up his own bad behavior by opportunistically claiming racism. That such arguments are tied to a sense that Gates was "playing the race card" is also seen in the title of the aforementioned Graham editorial, Colorblind Test Failed; It's Gates Who Plays Race Card. ${ }^{379}$

\section{Conclusion: Critiquing False Equivalencies}

Interestingly, Landor's comment seems to accept the rule of deference to the badge identified earlier as a product of hegemonic masculinity. ${ }^{380}$ If one violates that rule, it seems, resulting harassment is your own fault. Most notably for present purposes, one who violates the rule of deference forfeits the ability to claim racial bias. This assumes that an incident can only be a product of racial profiling or of a violation of the rule of deference, not both. This fits with the colorblind view of racism as an on/off switch. Absent explicit and expressed invidious racial motivations, an event is presumed wholly nonbiased. ${ }^{381}$ For that reason, post-racialism links up with Gates's machismo, in the form of his refusal to defer to the badge, to create an excuse for Crowley's arrest.

But the fact Gates is accused of "playing the race card" suggests that something more is going on than mere substitutions of machismo or arrogance as explanations for the arrest. The racial profiling claim is itself deemed to constitute "reverse" racism. ${ }^{382}$ Not only is the claim "It's because I'm black" apparently always wrong, it is injurious to the subject of the claim. Thus, in the New York Post article, Landor claims "Gates acted toward Sgt. Crowley based on his own prejudice, stereotyping a white policeman to be a racist." ${ }^{383}$ The slippage here is startling. As in the post-racial analysis of "playing the race card," because Gates cannot prove his claim of racial profiling with an explicit expression of racism, it is false. And being false, it is itself racism. This is what happens when machismo meets post-racialism: the very claim of racism is flipped into evidence of "reverse" racism. Here, post-racialism creates a false equivalence between Crowley's actual (albeit implicit) racial discrimination in the form of assuming Gates's guilt and Gates's act of, at worst, incorrectly accusing Crowley of intentional racial discrimination.

Just as post-racialists falsely make claiming racism equivalent with an act of racism, the City of Cambridge Review Committee's shared-responsibilities approach creates a false equivalence between the civilian and the police officer. The Committee seems to expect Gates to strive as mightily as a police officer in the effort to keep the peace. The report says that once Crowley explained his presence and Gates provided identification, "the behavior of both men should

378 Id. (quoting Lee Landor).

379 Graham, supra note 337, at 19.

380 See Cooper, Who's the Man?, supra note 13, at 697-98 (defining rule of deference to the badge); discussion supra Part III.A.2 (same).

381 See discussion supra Part III.B (making this argument).

382 See Gary Peller, Race Consciousness, 1990 Duke L.J. 758, 821 (criticizing notion of "reverse racism").

383 Cartwright \& Fermino, supra note 262, at 7. 
have begun to change." ${ }^{384}$ This is a false equivalency. The report acts as though a civilian who has been wrongly accused of a crime and treated brusquely by a public servant should be as mollified by the explanation as a police officer should be by proof there was no crime. But the civilian is harmed by the false accusation whereas the officer is not harmed by doing his job of investigating a false complaint. As Carbado explains in an autobiographical segment of his critique of racial profiling, it is painful to be wrongly accused by the police. ${ }^{385}$ In addition to being more harmed by the encounter than was Crowley, Gates was also less responsible for the encounter. Crowley is a police officer; he is supposed to be trained to deal with conflict. Gates is a professor; he is not trained to deal with conflict beyond those common to university classrooms. Moreover, despite the Committee's assertion to the contrary, it is not Gates's job to keep the peace. It was Gates's right to act obnoxiously when accused of a crime in his own home. It was Crowley's job to de-escalate the conflict. The Committee's attempt to impose "shared responsibilities" on Crowley and Gates thus creates a false equivalence between police officers and civilians.

In addition to criticizing the false equivalence between police officers and civilians created by narratives such as that in the Committee's report, we also need a scholarly program revealing that norms of masculinity, while invisible, strongly influence behavior, ${ }^{386}$ and that post-racialism, while explicitly progressive, hides implicit bias from view. ${ }^{387}$ This Article has been a starting point for that initiative.

384 Missed Opportunities, supra note 22, at 3.

385 Carbado, (E)racing, supra note 248, at 952-964.

386 See Cooper, Who's the Man?, supra note 13, at 687 (referring to "masculinity's transparency"); cf. FLAGG, supra note 320, at 4 (referring to "transparency phenomenon" whereby whiteness is invisible).

387 See Cho, supra note 29, at 1593 (referring to post-racialism as maintaining "white normativity"). 